Linköping Studies in Science and Technology

Dissertation No. 2101

\title{
Methods for Capacity Allocation in Deregulated Railway Markets
}

Abderrahman Ait-Ali

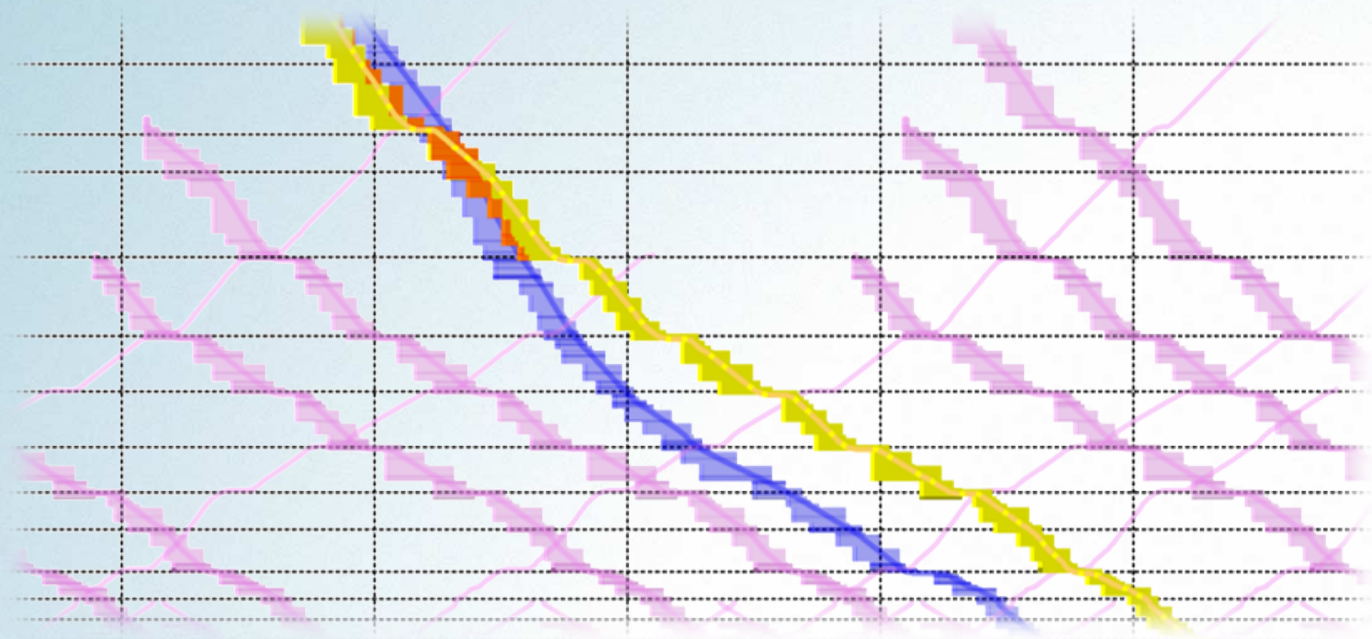




\title{
Methods for Capacity Allocation in Deregulated Railway Markets
}

\author{
Abderrahman Ait Ali
}

Supervised by Jonas Eliasson

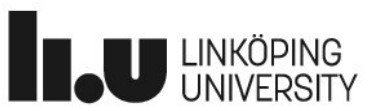

vti

Department of Science and Technology

Division of Communications and Transport Systems

Linköpings universitet, SE-601 74 Norrköping, Sweden

Norrköping 2020 
Methods for Capacity Allocation in Deregulated Railway Markets Abderrahman Ait Ali

Supervisor: Jonas Eliasson

Co-supervisors: Anders Peterson and Maria Börjesson

Linköping Studies in Science and Technology. Dissertation No. 2101

Copyrights (C) 2020 Abderrahman Ait-Ali, unless otherwise noted

Cover illustration is a graphical timetable from Railsys simulation software.

ISBN 978-91-7929-771-8

ISSN $0345-7524$

Printed by LiU-Tryck, Linköping, Sweden 2020 


\section{Abstract}

Faced with increasing challenges, railways around Europe have recently undergone major reforms aiming to improve the efficiency and competitiveness of the railway sector. New market structures such as vertical separation, deregulation and open access can allow for reduced public expenditures, increased market competition, and more efficient railway systems.

However, these structures have introduced new challenges for managing infrastructure and operations. Railway capacity allocation, previously internally performed within monopolistic national companies, are now conferred to an infrastructure manager. The manager is responsible for transparent and efficient allocation of available capacity to the different (often competing) licensed railway undertakings.

This thesis aims at developing a number of methods that can help allocate capacity in a deregulated (vertically separated) railway market. It focuses on efficiency in terms of social welfare, and transparency in terms of clarity and fairness. The work is concerned with successive allocation of capacity for publicly controlled and commercial traffic within a segmented railway market.

The contributions include cost benefit analysis methods that allow public transport authorities to assess the social welfare of their traffic, and create efficient schedules. The thesis also describes a market-based transparent capacity allocation where infrastructure managers price commercial train paths to solve capacity conflicts with publicly controlled traffic. Additionally, solution methods are developed to help estimate passenger demand, which is a necessary input both for resolving conflicts, and for creating efficient timetables.

Future capacity allocation in deregulated markets may include solution methods from this thesis. However, further experimentations are still required to address concerns such as data, legislation and acceptability. Moreover, future works can include prototyping and pilot projects on the proposed solutions, and investigating legal and digitalisation strategies to facilitate the implementation of such solutions.

Keywords: railway capacity; capacity allocation; train timetable; cost benefit analysis; deregulated market. 



\section{Sammanfattning}

Med ökande utmaningar har järnvägar runt om i Europa genomgått stora reformer som syftar till att förbättra järnvägssektorns effektivitet och konkurrenskraft. Nya marknadsstrukturer såsom vertikal separering, avreglering och öppet tillträde för flera operatörer kan möjliggöra minskade offentliga kostnader, ökad marknadskonkurrens och effektivare järnvägssystem.

Denna omreglering av järnvägsmarknaderna har dock skapat nya utmaningar för hanteringen av järnvägsinfrastruktur och drift. Tilldelning av järnvägskapacitet, vilket tidigare sköttes inom nationella monopolföretag, måste nu göras av en infrastrukturförvaltare (infrastructure manager). Förvaltarens kapacitetstilldelning till olika (ofta konkurrerande) licensierade järnvägsföretag (railway undertakings) måste samtidigt vara transparent, rättvis och leda till ett effektivt kapacitetsutnyttjande.

I denna avhandling utvecklas metoder som kan användas av en infrastrukturförvaltare för att tilldela kapacitet i en avreglerad järnvägsmarknad. Den fokuserar på samhällsekonomiskt effektiva utfall men även transparens, tydlighet och rättvisa.

Avhandlingens bidrag omfattar samhällsekonomiska analysmetoder som gör det möjligt för regionala kollektivtrafikmyndigheter att bedöma den samhällsekonomiska effektiviteten för deras trafikering och skapa ett effektivt utbud. Med dessa metoder som utgångspunkt beskrivs en marknadsbaserad och transparent tilldelningsprocess för kapacitet där infrastrukturförvaltare prissätter kommersiella tåglägen för att lösa kapacitetskonflikter med offentligt kontrollerad trafik. Dessutom utvecklas optimeringsmetoder för att estimera passagerarefterfrågan och för att skapa effektiva tågtidtabeller.

Framtida kapacitetstilldelning på avreglerade marknader kan inkludera lösningsmetoder från denna avhandling. Ytterligare experiment krävs dock fortfarande för att hantera problem såsom data, lagstiftning och godtagbarhet. Dessutom kan framtida arbete omfatta prototyper och pilotprojekt av de föreslagna lösningarna och undersöka lagliga och digitaliseringsstrategier för att underlätta implementeringen av sådana lösningar.

Nyckelord: spårkapacitet; kapacitetstilldelning; tågtidtabell; samhällsekonomisk analys; avreglerad marknad. 



\section{Acknowledgements}

Thanks to the support of many people, this doctoral thesis is the result of a life changing positive experience. I would like to acknowledge you here, person by person, but I will surely be unable to mention you all. I hereby thank you ALL from the heart of my heart.

First and foremost, Jonas, no words can describe your involvement, guidance and support to start, do and finish this journey. You have been the supervisor and the friend that I have wished to have. Without you, much of this experience would not be a reality. Stort TACK Jonas!

Maria and Anders, my co-supervisors, you have been immensely helpful. Maria, you have been supportive from the beginning until the end. Anders, thank you for stepping up to help me finish this journey. Tackar!

Per Olov Lindberg, Jan-Eric Nilsson and Martin Aronsson, my first tutors, you have helped me begin this journey. Jan-Eric together with PO, your experience and expertise made my first research work more rigorous. Martin, discussing with you have always been insightful. Tack alla!

Jennifer Warg, Emanuel Broman, Victoria Svedberg, Sara Gestrelius, Emma Solinen, Carl-William Palmqvist, Johan Högdahl, Ingrid Johansson, Niloofar Minbashi and Félix Vautard, the future of (Swedish) railway research, it has been very enjoyable to work and/or discuss with you. Jenny, you have always been helpful. Emanuel, it has been nice to share most of this journey with you. Tack alla för allt!

Hans Dahlberg, Mattias Haraldsson \& Jan-Erik Swärdh, Jan Lundgren, the project partners from Trafikverket, VTI and Linköping University (LiU), respectively. Hasse, you have been an enthusiast project leader from the beginning. Mattias, Jan-Erik and Jan, you have helped make my work environment more productive and enjoyable. Tack ska ni ha!

I will not forget to express my gratefulness to Yves Crozet for kindly accepting to be my opponent for the final defence, to Karin Brundell-Freij for the final seminar, and to Tomas and Mats for the KTS start seminar. I also express my gratitude to all the members of the examination board, namely Gunnar Isacsson, Jan Persson and Siri Pettersen Strandenes.

I was lucky that my journey went through different workplaces, i.e., KTH, VTI (Stockholm), LiU (Norrköping) and IFSTTAR-LVMT (Paris). My former colleagues at KTH (Alyn, Anders, Athina, Behzad, Bibbi, Bolle, David, Dimas, Erik, Gerhard, Hans, Hugo, Isak, Jiali, Joel, Jonas, Joram, 
Josef, Juan, Markus, Masoud, Matej, Oskar, Roberto, Soumela, Tasos, Todor, Wei, Wilco, Yusak), the new ones at LiU (Alan, Anna, Antzela, Christiane, Clas, Ghazwan, Joakim, Kalle, Martin, Mats, Nikki, Nikos, Nils, Therese, Tomas, Viveka) and VTI (Ajsuna, Ary, Chengxi, Disa, Ida, Inge, Jiali (again), Johanna, Kristofer, Lisa, Noor, Roger, Tomas (again), Ulrika), and my hosts at IFSTTAR-LVMT (Martin, Nicolas, Paola, Sophie), you have all made my journey more joyful.

My dearest friends (Abdessamad, Ahmed, André, Anass, Aymen, Driss, David, Hafid, Habib, Hicham, Othmane, Rachid, Salah, Taoufiq, Yassine, Yassir, Youssef), I am grateful to have you all. My mom, dad and closest relatives, you have always been supportive. Amina, thank you for your continuous and overwhelming love.

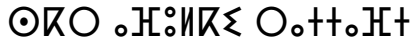 \\ Do good and you will find it!
}

Stockholm, 2020-10-01

Abdou (with $\bigcirc$ ) 


\section{Preface}

This doctoral thesis is the culmination of research conducted between 2015 and 2020 at the Royal Institute of Technology (KTH), the Swedish National Road and Transport Research Institute (VTI) and Linköping University (LiU) in Sweden. Funded by the Swedish Transport Administration (Trafikverket), the thesis is part of the SamEff project (Samhällsekonomiskt effektiv tilldelning av järnvägskapacitet) which stands for societally efficient railway capacity allocation.

The thesis consists of five papers appended to an introductory essay.

\section{List of included papers}

Paper 1 (P1): Ait-Ali and Eliasson (2019). A Survey of Railway Deregulation in Europe. Submitted for journal publication.

Paper 2 (P2): Ait-Ali et al. (2020). Pricing Commercial Train Path Requests Based on Societal Costs. Published in Transportation Research Part A: Policy and Practice, Volume 132, February 2020, Pages 452-464.

Paper 3 (P3): Ait-Ali et al. (2020). Are commuter train timetables consistent with passengers' valuations of waiting times and in-vehicle crowding? Submitted for journal publication.

Paper 4 (P4): Ait-Ali et al. (2020). Disaggregation in Bundle Methods: Application to the Train Timetabling Problem. Published in Journal of Rail Transport Planning \& Management, 100200.

Paper 5 (P5): Ait-Ali and Eliasson (2020). The Value of Additional Data for Public Transport Origin-Destination Matrix Estimation. Submitted for journal publication.

\section{List of related (but not included) papers}

Related paper 1 (RP1): Ait-Ali et al. (2017). Measuring the Socio-economic Benefits of Train Timetables Application to Commuter Train Services in Stockholm. Published in Transportation Research Procedia, 27 , 849-856. 
Related paper 2 (RP2): Warg et al. (2019). Assessment of Commuter Train Timetables Including Transfers. Published in Transportation Research Procedia, 37, 11-18.

Related paper 3 (RP3): Ait-Ali and Eliasson (2019). Dynamic OriginDestination Estimation Using Smart Card Data: An Entropy Maximisation Approach. Published in arXiv:1909.02826.

\section{Conferences}

Parts of the work in this thesis include journal and conference papers. Most of these papers were disseminated and presented at local and international conferences and seminars. Table 1 lists the international conferences where papers have been disseminated and presented.

Table 1. International conferences and disseminated papers.

\begin{tabular}{|c|c|}
\hline Paper(s) & International conference \\
\hline $\mathrm{P}_{3}$ & $\begin{array}{l}\text { European Conference of Society for Benefit-Cost Analysis, } \\
26^{\text {th }}-27^{\text {th }} \text { November } 2019 \text {, Toulouse }- \text { France }\end{array}$ \\
\hline $\mathrm{P}_{2}, \mathrm{RP}_{3}$ & $\begin{array}{l}\text { 8th International Conference on Railway Operations Model- } \\
\text { ling and Analysis, } 17^{\text {th }}-20^{\text {th }} \text { June } 2019 \text {, Norrköping - Sweden }\end{array}$ \\
\hline $\mathrm{RP} 1$ & $\begin{array}{l}21^{\text {st }} \text { EURO Working Group on Transportation Meeting, } 17^{\text {th }} \text { - } \\
19^{\text {th }} \text { September } 2018 \text {, Braunschweig - Germany }\end{array}$ \\
\hline $\mathrm{P}_{5}$ & $\begin{array}{l}29^{\text {th }} \text { European Conference on Operational Research EURO } \\
2018,9^{\text {th }}-11^{\text {th }} \text { July } 2018 \text {, Valencia - Spain }\end{array}$ \\
\hline $\mathrm{RP} 2$ & $\begin{array}{l}20^{\text {th }} \text { EURO Working Group on Transportation Meeting, } 4^{\text {th }}- \\
6^{\text {th }} \text { September 2017, Budapest }- \text { Hungary }\end{array}$ \\
\hline $\mathrm{P}_{4}$ & $\begin{array}{l}7^{\text {th }} \text { International Conference on Railway Operations Model- } \\
\text { ling and Analysis, } 4^{\text {th }}-7^{\text {th }} \text { April } 2017 \text {, Lille - France }\end{array}$ \\
\hline
\end{tabular}

\section{Author contribution statement}

Ait-Ali, A., the author of this thesis, is the main contributor in the included papers. He has conducted the research, literature review, model development, experimentation as well as documentation. Eliasson, J., the main supervisor, has provided research ideas, support, advice, and extensive review of this thesis, all the included and related papers. Warg, J., co-author of $\mathrm{P} 2$, has collaborated with the main author in problem formulation, experimental design and writing the paper. Lindberg, P. O., co-author of $\mathrm{P}_{4}$, has provided the main research idea. All co-authors have helped in result analysis and/or paper review. 


\section{Terminology}

The following glossary presents definitions (in alphabetical order) of the main terminology (italicised when first used) that is adopted in this thesis.

The definitions are based on a number of references from railway and economics. Most of the railway-related definitions are borrowed from the glossary of terms by RNE (2017). Definitions of economics-related terms are mainly from the book by Wetzstein (2013).

Swedish translations are checked using Sweden's national term bank database (Rikstermbanken, 2019).

Annual timetable (årlig tågplan): yearly constructed schedule listing the times and the locations at which certain events, e.g., arrivals and departures, are expected to take place (same as the working timetable).

Commercial train services (kommersiella tågutbud): train services that are operated on a profit-maximising basis, e.g., freight, long distance passenger trains (in contrast to subsidised train services).

Competitive tendering (konkurrensutsatt upphandling): process of bidding to win the rights to run train services, i.e., for-track competition. Concession (koncession): management contract giving the right to operate a service over a defined period (typically several years) subject to meeting certain requirements, often awarded by competitive tendering. Consumer surplus (konsumentöverskott): benefit that is received by the consumers of a product or a service from the difference between the price and the willingness-to-pay.

Corner solution (hörnlösning): an optimal solution in a point where several linear constraints meet, making its location independent of certain input parameters.

Cost benefit analysis (kostnads-nyttoanalys): approach to calculate and compare the benefits and costs of a certain project or policy.

Deregulation (avreglering): process of removing barriers to entry in the market, and thus increase competition.

Dispatching, traffic control (trafikledning): directing and facilitating the movement of trains in a certain area and period of time.

EU directive (EU-direktiv): legal act of the EU that needs to be transposed into national law in the member states without dictating how.

EU regulation ( $E U$-förordning): legal act of the EU that becomes immediately enforceable as law in all member states simultaneously.

Framework agreement (ramavtal): setting out capacity allocation rights over a period longer than one working timetable. 
Franchising (franchise): exclusive right to operate a service under a higher degree of specification (compared to concession, e.g. setting fare levels and financial risks) and may involve payments between the transport authority and the franchisee.

Freight traffic (godstrafik): railway traffic transporting goods (in contrast to passenger traffic).

Gamification (spelifiering): use of game principles and design to solve problems in non-game contexts, e.g., to improve productivity or for learning.

Grandfather right (hävdvunnen rättighet, oöversatt): rights and rules favoring incumbents at the expense of new entrants.

Headway (tågseparation): time or distance between two consecutive trains.

Incumbent operator (etablerad operatör): national railway undertaking(s) or operator(s) traditionally owning rolling stock, responsible for production, operations, maintenance and infrastructure (before the vertical separation and the deregulation).

Infrastructure manager (infrastrukturförvaltare): body responsible for administering rail infrastructure and managing its facilities.

Monopoly (monopol): when an actor is the only supplier of a certain service or product in a market.

Nationalisation (nationalisering): process of converting private assets to public ones owned by the state (in contrast to privatisation).

Network statement (järnvägsnätsbeskrivning): document which sets out in detail the general rules and procedures for allocating railway capacity, including information required for capacity applications.

Open access (öppet tillträde): process by which non-incumbent operators can also access the infrastructure, enabling them to run services complementing or competing with others, i.e., on-track competition.

Passenger traffic (persontrafik): railway traffic transporting passengers (in contrast to freight traffic).

Privatisation (privatisering): process of converting state-owned public assets to private ones (in contrast to nationalisation).

Producer surplus (producentöverskott): the monetary value that is gained by the producers of a product due to the difference between the price and their production cost or willingness-to-sell.

Public service obligation (trafikeringsplikt): responsibility of the railway undertaking to maintain a certain level of public services, e.g., number of train departures or frequency, ticket prices.

Public utility (allmännyttig tjänst): service provided on a regulated public infrastructure such as electricity, water and telecommunication.

Publicly controlled (or subsidised) train services (subventionerade tågtjänster): train services where timetables and fares are 
determined by a public agency, presumably to maximise social welfare (in contrast to commercial train services, where a profit-maximising company decides timetables and fares).

Railway capacity allocation (järnvägskapacitetstilldelning): process where capacity is granted to a railway undertaking (or other applicants) by the relevant capacity allocation body (infrastructure manager). Railway regulator (regulator): independent, official regulatory body for rail; its duties and powers are set out in the national legislation.

Railway undertaking (järnvägsföretag): any licensed public or private entity, the principal business of which is to provide services for the transport of goods and/or passengers by rail.

Reserve capacity (reservkapacitet): capacity kept available within the final working timetable allowing quick and appropriate responses to ad hoc requests.

Rolling stock (rullande materiel): collective term for the railway fleet describing all the vehicles on a track (in contrast to fixed stock or infrastructure).

Social cost (samhällsekonomisk kostnad): total cost incurred by the society including consumer, producer and external costs. (same as the societal cost, in contrast to the social surplus).

Track access charges (banavgifter): fees that are paid to the infrastructure manager by an operator for running trains on its infrastructure. Train path (tågläge): definition of a train's route in terms of time and space with details of locations at which it will pass, including any activities that the train will perform, e.g., train crew, locomotive changes.

Train timetabling (tidtabelläggning): process of consultation and planning to define expected train movements taking place on the infrastructure during a certain period time.

Transaction costs (transaktionskostnader): costs related to the economic interaction between separate entities.

Vertical separation (vertikal separation): separation of infrastructure management and railway operations (e.g., train services). 



\section{Contents}

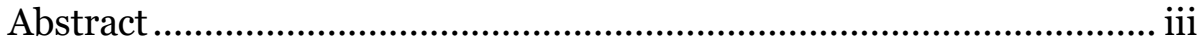

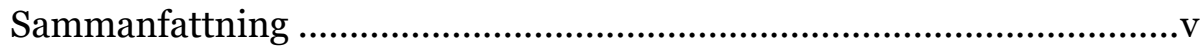

Acknowledgements .................................................................................vii

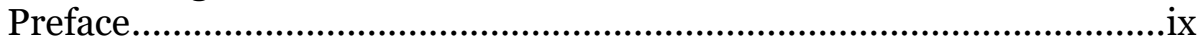

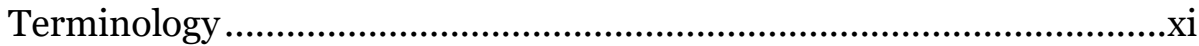

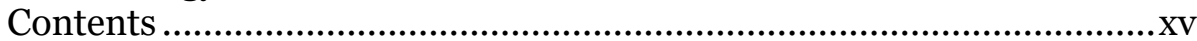

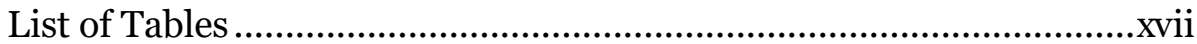

List of Figures .................................................................................

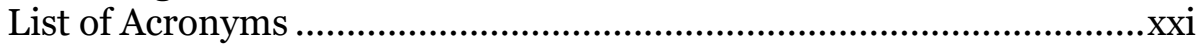

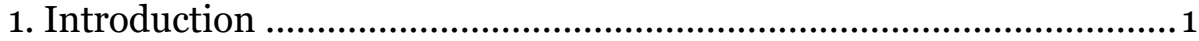

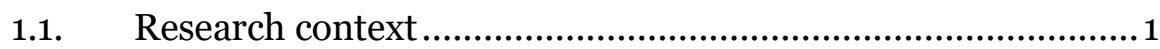

1.2. Thesis outline ....................................................................... 3

1.3. Delimitation ......................................................................... 3

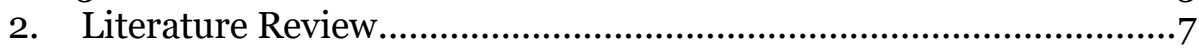

2.1. Railway capacity..................................................................

2.2. Capacity allocation ............................................................... 8

2.3. Market deregulation ............................................................. 8

2.4. European context ................................................................... 11

2.5. Swedish capacity allocation .................................................12

2.6. Existing research and experiments..........................................13

3. Conducted Research .......................................................................19

3.1. Challenges and research gaps ...............................................19

3.2. Research questions ................................................................ 20

3.3. Research methodology ............................................................. 21

3.4. Market-based capacity allocation ............................................ 23

3.5. Subsidised traffic .................................................................... 25

3.6. Commercial traffic .................................................................27

3.7. Discussion ............................................................................. 29

4. Contributions and Future Works.....................................................35

4.1. Summary of the papers .............................................................35

4.2. Main contributions ................................................................. 39

4.3. Conclusions and future works ................................................41

References............................................................................................ 43

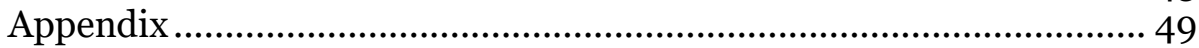

Included Papers …............................................................................... 51

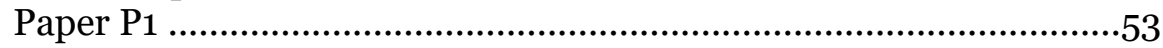

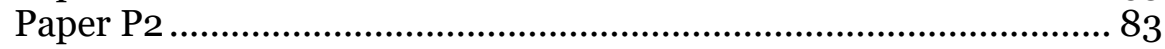

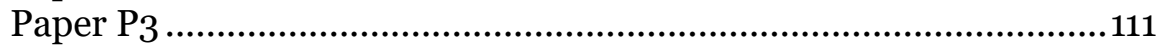

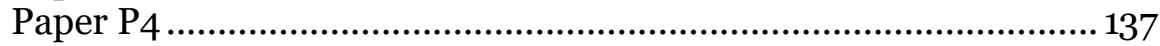

Paper P 5 …................................................................................169 



\section{List of Tables}

Table 1. International conferences and disseminated papers..................

Table 2. EU packages and main topics in the directives..........................

Table 3. Research methodology and adopted methods...........................

Table 4. Main contributions and interested stakeholder(s).

22 



\section{List of Figures}

All the figures in this thesis are the author's own work, unless otherwise noted.

Figure 1. Timeline of vertical separation and EU railway packages.......

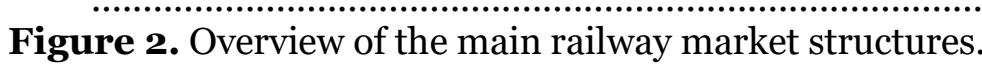

Figure 3. Example of a deregulated market structure in Europe.

Figure 4. Overview of Swedish railway capacity allocation

............................................................................................... 13

Figure 5. Flowchart of the adopted top-down research methodology. ..

Figure 6. Successive capacity allocation in a segmented market.

Figure 7. Overview of capacity allocation for publicly controlled traffic.

Figure 8. Illustration of different train path adjustments

Figure 9. Example of commercial train path pricing (in SEK) 



\section{List of Acronyms}

$\begin{array}{ll}\text { CBA } & \text { Cost Benefit Analysis } \\ \text { CERRE } & \text { Centre on Regulation in Europe } \\ \text { Cx } & \text { Contribution x (x is a number from 1 to 10) } \\ \text { EC } & \text { European Commission } \\ \text { EM } & \text { Entropy Maximisation } \\ \text { EU } & \text { European Union } \\ \text { GDP } & \text { Gross Domestic Product } \\ \text { ICT } & \text { Information and Communications Technology } \\ \text { IM } & \text { Infrastructure Manager } \\ \text { IP } & \text { Integer Program } \\ \text { ITF } & \text { International Transport Forum } \\ \text { KPI } & \text { Key Performance Indicator } \\ \text { MIP } & \text { Mixed Integer Program } \\ \text { MPK } & \text { Marknadsanpassad Planering av Kapacitet } \\ & \text { (English: Market-adapted Planning of Capacity) } \\ \text { OD } & \text { Origin Destination } \\ \text { OECD } & \text { Organisation for Economic Cooperation and Development } \\ \text { PPP } & \text { Public Private Partnerships } \\ \text { PSO } & \text { Public Service Obligation } \\ \text { PT } & \text { Public Transport } \\ \text { PTA } & \text { Public Transport Authority } \\ \text { PX } & \text { Paper x (x is a number from 1 to 5) } \\ \text { RKTM } & \text { Regional kollektivtrafikmyndighet (in Swedish) } \\ \text { RMSE } & \text { (English: Regional Public Transport Authority or PTA) } \\ \text { RNE } & \text { Root Mean Square Error } \\ \text { RPx } & \text { RailNetEurope } \\ \text { RQx } & \text { Related Paper x (x is a number from 1 to 3) } \\ \text { RU } & \text { Research Question x (x is a number from 1 to 5) } \\ \text { SEK } & \text { Railway Undertaking } \\ \text { SERA } & \text { Swedish Krona (1 Euro is around 10 SEK) } \\ \text { SJ } & \text { Single European Railway Area } \\ \text { SL } & \text { Statens Järnvägar } \\ \text { TTP } & \text { Storstockholms Lokaltrafik (in Swedish) } \\ \text { TTR } & \text { (English: Greater Stockholm Local Transit) } \\ \text { UIC } & \text { Train Timetabling Problem } \\ \text { WTP } & \text { Union Internationale des Chemins de fer (in French) } \\ & \text { (English: International Union of Railways) } \\ \text { Willingness-To-Pay } \\ \end{array}$





\section{Chapter 1}

\section{Introduction}

Do not say a little in many words but a great deal in a few

Pythagoras, Greek philosopher 



\section{Introduction}

States long adopted a laissez-faire policy in early railways, allowing private companies to build, operate, maintain, and hence own railway systems, i.e., privatised railways. Some developments (e.g., passenger trains, fierce competition between investors or railway mania and the industrial revolution) made governments pay increasing attention. Many railways were therefore nationalised, and thus operated by monopolistic state-owned companies providing both passenger and freight traffic.

During the late $20^{\text {th }}$ century, national railways have been facing increasing challenges due to efficiency and cost problems, and competition from other modes. Several railway markets, mainly in the European Union (EU), have been subsequently reformed by splitting their monopolistic national railways into infrastructure management and train services. This splitting, also called vertical separation, allows for opening the railway market to competition. New (domestic or foreign) railway companies may provide train services, a process often referred to as deregulation which reduces state market control.

By deregulating their railways, governments aim to reduce public expenditures, increase service quality, and improve system efficiency. For this to succeed, there is still need for instruments to intervene, i.e., regulating the deregulation. An important element in this context is the allocation of railway capacity which faces new challenges due to the deregulation. In other words, the previously closed internal capacity allocation, within monopolistic national railway companies, needs to be replaced with a more transparent and (still) efficient allocation of available capacity to the different (possibly competing) companies in the market. This task is the main problem that this thesis attempts to address.

This first chapter introduces more relevant information to understand the research context and motivation of this work. It also presents the structure of the thesis, and finally, states its delimitation.

\subsection{Research context}

With decreasing efficiency and increasing spending, state-controlled railways came under pressure, and a trend of deregulation reforms emerged which allowed private actors in the market once again (Laurino et al., 2015). Sweden was first to start deregulating its national market (as early as 1988) after vertically separating railway services from infrastructure management (Hansson and Nilsson, 1991). 


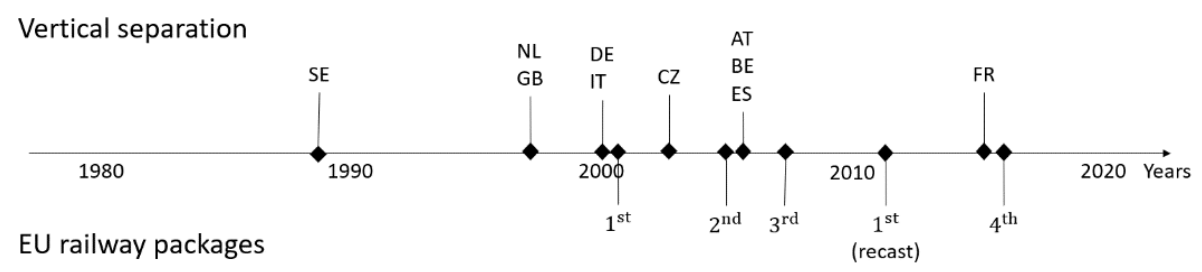

Figure 1. Timeline of vertical separation and EU railway packages.

Following the 1991/440/EEC first directive (EC, 1991), several EU member states adopted vertical separation as illustrated in the timeline presented in Figure 1. The directive allows one of three alternatives: accounting, organisational or institutional separation. The first type guarantees separate financial accounts, the second is about independent units within one larger institution, and the third refers to the complete separation as in Sweden. This resulted in various market structures throughout Europe but all have at least a vertical separation in accounting (Monami, 2000, Nash, 2008).

Following further EU directives and regulations (grouped as railway packages), train services in different market segments have been gradually opened for competition (EC, 2001). Further calls from the European Commission (EC) aimed, among other things, to establish a Single European Railway Area (SERA) as stipulated by the 34/EC SERA directive, a recast of the $1^{\text {st }}$ railway package $(\mathrm{EC}, 2012)$. The directives have also aimed to promote competition, interoperability, transparency and efficiency, see Appendix 1: EU directives.

In the context of railway capacity allocation, transparency means that all the process is comprehensive, clear and above all non-discriminatory to any of the market players. However, efficiency may be interpreted in various ways depending on the national railway legislation. In Sweden, the objective of railway capacity allocation is to achieve maximal socioeconomic or societal efficiency (samhällsekonomisk effektivitet in Swedish) meaning that the net social surplus is maximised including benefits for all consumers and producers as well as all external effects, see Appendix 2: Swedish railway law.

The contributions of this thesis attempt to address the problem of socioeconomically efficient and transparent capacity allocation in vertically separated and deregulated railways, e.g., Sweden. 


\subsection{Thesis outline}

Four chapters form the thesis. This $1^{\text {st }}$ chapter introduces the research setting by presenting the research context, the thesis outline and delimitation. Chapter 2 presents the relevant background information and terminology on railway capacity, its allocation and market deregulation. It also provides a review of the literature including related existing research and experiments with focus on Europe and Sweden. The conducted research is described in the $3^{\text {rd }}$ chapter which starts with the gaps and challenges, and the research questions follow with a presentation of the methodology. A discussion of the conducted research concludes the chapter. The contributions and future works in chapter 4 conclude the thesis.

Relevant excerpts from the European and Swedish legislation can be found in the two appendices. Finally, all the included papers are appended to this thesis.

\subsection{Delimitation}

The scope of this thesis is delimited in several dimensions. First and foremost, the focus is mostly on the efficiency of the capacity allocation, rather than its transparency. Second, specific allocation contracts such as franchising, concessions and framework agreements, although important, are not studied in detail but only briefly mentioned. However, we study situations of capacity conflicts between publicly controlled and commercial train services regardless of the allocation contracts. Moreover, certain market segments (e.g., infrastructure maintenance) and allocation steps (e.g., ad hoc) are only briefly discussed. Furthermore, dispatching or real time traffic control aspects (e.g., timetable robustness and train punctuality) are not considered, but these are well developed in the literature (Andersson et al., 2013), and can therefore be included in a later stage of the allocation. Last but not least, legal issues are only briefly mentioned and discussed. 



\section{Chapter 2}

\section{Literature Review}

'Många vet mycket, ingen vet allt'

Many know much, but nobody knows everything

Swedish proverb 



\section{Literature Review}

In this $2^{\text {nd }}$ chapter, background information on railway capacity, its allocation and market deregulation are presented while introducing relevant terminology. Related existing research and experiments are also briefly reviewed focusing on the European and Swedish context.

\subsection{Railway capacity}

In the railway sector, capacity has different meanings depending on the context where it is used. Although no unique definition exists, railway capacity is an important concept that can be defined and analysed based on specific aspects (Petersen, 1974). For instance, it is highly affected by factors such as infrastructure (number of tracks and network design), type of train traffic (e.g., freight, high-speed or commuter trains) and other operational factors (Forsgren, 2003, Abril et al., 2008).

One definition, also used in Sweden, is from the 406 code by the International Union of Railways (IUC) which states that capacity of any infrastructure is the number of possible paths in a time window (UIC, 2004). Such a number may depend on additional factors such as the path mix (traffic heterogeneity), service quality and other considerations for constructing train timetables (Goverde and Hansen, 2013).

In the context of railway capacity allocation, RailNetEurope (RNE), in its glossary of terms, refers to capacity as the actual train path which describes the infrastructure needed for running a train between two places over a given period of time, i.e., time-space taken up in the annual timetable by the passage of the train including safety margins (RNE, 2017). Later in this thesis, we will see that train paths include certain flexibility and can be adjusted during allocation.

Railway capacity at certain parts of the infrastructure may depend on (or affect) that of other parts in the network. For instance, (primary) delays in one place may cause (secondary) delays in others, or improved accessibility on some parts may induce demand on others. Such network effects indicate that capacity analysis is combinatorial in nature, and that most related problems are hard to solve using state-of-the-art solvers, e.g., train timetabling (Caprara et al., 2002). 


\subsection{Capacity allocation}

The allocation of railway capacity refers to the process where train path requests are granted by the relevant capacity allocation body, often called infrastructure manager (IM), to capacity applicants or train operators, also called railway undertakings (RUs). The allocated capacity can be used for running freight or passenger trains as well as for infrastructure maintenance. The IM is responsible for the allocation based on specific conditions and rules, compiled in the national network statement. Such allocation is repeated on a yearly basis to construct a new annual timetable specifying when and where trains run (RNE, 2017).

Unlike road traffic with an ad hoc allocation of capacity (queues can possibly be building up, i.e., road congestion), railway capacity must be planned and allocated beforehand (van Wee et al., 2013). Thus, capacity congestion in railways may emerge when the available capacity is not enough to include all the requested train paths. Capacity allocation is therefore fundamental in the railway sector for prior planning of the traffic, and for solving capacity conflicts, if any.

When allocating capacity, the IM has certain flexibility to adjust and reschedule the original train path requests. Thus, allocating capacity means including the (adjusted) requested train paths in the annual timetable. Each request represents a plan for a certain service, such as a freight or passenger trains. Such services differ in many ways, e.g., speed, distance, publicly controlled or commercial, and therefore express varying requirements. Furthermore, how capacity is allocated may also depend on the structure of the market, e.g., existing (or dominant) complementary or competing train services, degree of market competition and deregulation (Gibson, 2003).

\subsection{Market deregulation}

Railways are often referred to as examples of natural monopoly due to their substantial initial fixed costs (De Palma and Monardo, 2019). Other examples can be found in public utility networks such as gas, electricity and water. In natural monopolies such as railways, it is more practical to have a monopoly that provides the railway network. Hence, the early monopolistic and highly regulated national railways.

With the emergence of market deregulation trends in the railway sector, new structures appeared which vary from one country to the other due to various reasons, e.g., political, economic and geographical (Laurino et 
al., 2015). One fundamental difference between these markets is their degree of vertical separation (or integration) which refers to the division of responsibilities between infrastructure management and rail services. Another important difference is the level of deregulation, i.e., the horizontal relationship between the different actors in a market segment with similar roles and responsibilities (e.g., RUs).

These fundamental differences lead to four main structures as illustrated in Figure 2 where each arrow indicates the movement from one structure to another, either separation or integration in the horizontal or vertical dimension. In the same figure, a railway company (large grey box) may be responsible for rail services and/or the network (smaller white boxes).

Contrasting market structures (and segments) have distinct characteristics, and therefore need different capacity allocation principles (Gibson, 2003). In vertically integrated markets (i.e., top in Figure 2), capacity allocation is internally administered, and reduced to the so-called train timetabling problem (TTP) where the monopolistic company constructs a feasible train timetable that maximises the company's objective function (Brännlund et al., 1998, Caprara et al., 2002). This is different for vertically separated markets (i.e., bottom in Figure 2) with separate IMs. Railway deregulation allows for the presence of actors (RUs) other than the incumbent operator(s). In order to allocate capacity, the IM needs to accommodate different (sometimes conflicting) train path requests from RUs, and settle all the possible disputes. RUs are usually required to pay track access charges for their respective allocated paths (Freebairn, 1998, Bouf et al., 2005).

Each structure has pros and cons (Mizutani et al., 2015, Abbott and Cohen, 2017). On the one hand, integration is better for reducing transaction costs between separate entities which are working together (Merkert, 2012, Merkert and Nash, 2013). On the other hand, separation, if managed well, can increase competition and thereby productivity and service quality. However, if competition is not well regulated, market inefficiencies may emerge, for instance due to anti-competitive practices by certain RUs leading to market outcomes that are far from maximising social welfare (Broman and Eliasson, 2019). 


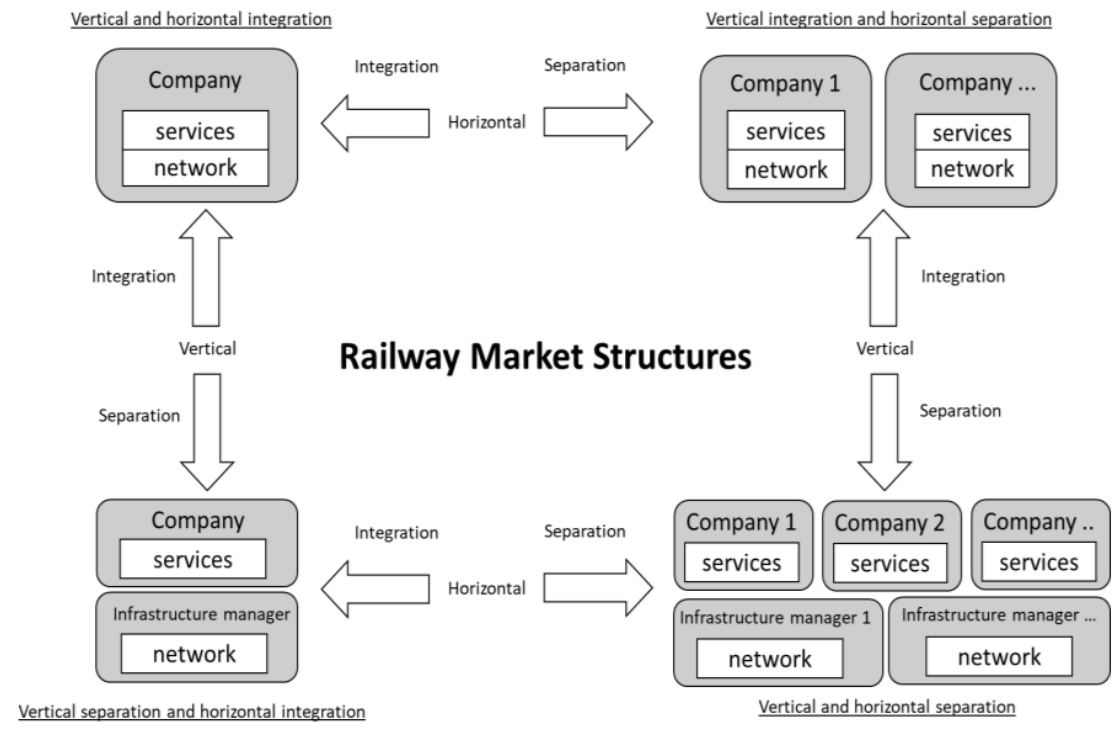

Figure 2. Overview of the main railway market structures.

In what follows, the thesis mostly focuses on capacity allocation in vertically separated (and deregulated) markets with open-access of the kind mostly found in EU markets, and in particular the Swedish railway system (Jensen and Stelling, 2007, Alexandersson and Rigas, 2013). Most European railways are vertically separated and deregulated with horizontal separation in services, see Figure 3. This structure aims at stimulating competition by allowing new (possibly foreign) companies to provide services alongside, often in competition with, the incumbent (or the previous monopolistic national company), if any. Interoperability is thus required for licensed companies to provide services across the $\mathrm{Eu}-$ ropean SERA market (Crozet et al., 2012).

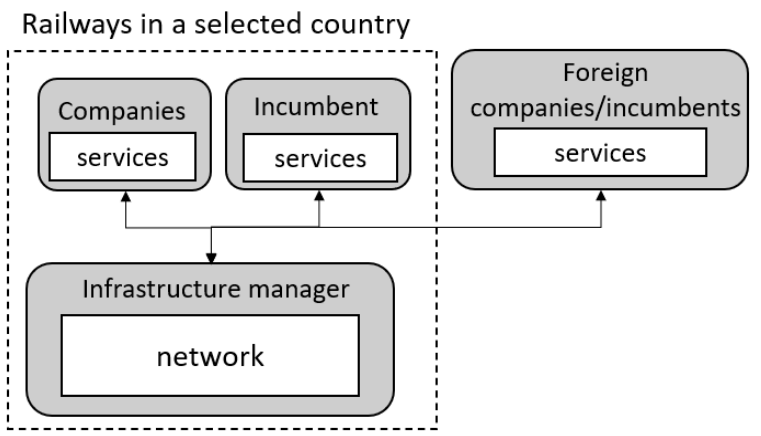

Figure 3. Example of a deregulated market structure in Europe. 


\subsection{European context}

As part of the European reforms, several member states adjusted their market structures and national railway legislation to EU policy guidelines (Monami, 2000, Nash et al., 2014). The EC has introduced several railway packages as guidelines to help implement the deregulation (EC, 1991, EC, 2001, EC, 2012). An overview of the packages and main topics of the corresponding directives is presented in Table 2.

Table 2. EU packages and main topics in the directives.

\begin{tabular}{lll}
\hline Package & Year & Main topics \\
\hline $1^{\text {st }}$ & 2001 & $\begin{array}{l}\text { Vertical separation for market deregulation: } \\
\text { cross-border freight, access charges, licensing }\end{array}$ \\
$2^{\text {nd }}$ & 2004 & $\begin{array}{l}\text { Integrated European railway area: } \\
\text { safety, interoperability, national freight } \\
3^{\text {rd }}\end{array}$ \\
2007 & $\begin{array}{l}\text { International passenger: } \\
\text { open access, subsidised services, interoperability } \\
\text { Domestic passenger services: } \\
\text { interoperability, governance, licensing }\end{array}$ \\
$4^{\text {th }}$ & 2016 \\
\hline
\end{tabular}

A timeline of these packages was also previously presented in Figure 1. The $1^{\text {st }}$ package (initiated with directive 91/440 from 1991) was an early attempt to set certain guidelines for market deregulation and capacity allocation (EC, 2001). Accordingly, all member states are required to have at least vertical separation in terms of accounting. A recast established, among others, principles for interoperability in the SERA markets (EC, 2012). The packages that followed focused on the successive deregulation of different market segments, e.g., cross-border freight (2001), national freight (2004), international passenger (2007) and domestic passenger (2016) as part of the more recent $4^{\text {th }}$ railway package (EC, 2016).

In European deregulated markets, the IM publishes the national network statement on a yearly basis providing guidelines on how capacity is allocated for the licensed RUs. The allocation generally starts one year (noted X-12) before adopting the new annual timetable. The IM receives capacity (train path) requests which are formulated by capacity applicants (RUs). A draft of the annual timetable is prepared by the IM for coordination with RUs to settle potential capacity conflicts.

When unresolved through negotiations and voluntary compromises, capacity conflicts are settled unilaterally by the IM using predetermined priority criteria. Lines (and time periods) where such conflicts occur are 
declared congested, and capacity analysis is conducted by the IM for reinforcement plans to improve the capacity supply.

Once the draft is published, the late train path requests are received and allocated depending on the available reserve capacity. This ad hoc allocation of capacity continues during the year, even after the start day of the annual timetable, i.e., between $\mathrm{X}$ and $\mathrm{X}+12$. The allocation is supervised by the railway regulator, often an independent governmental body. An overview of the allocation is illustrated in Figure 4.

\subsection{Swedish capacity allocation}

The Swedish railway market was managed by the Swedish State Railways SJ (Statens Järnvägar) until 1988, when infrastructure management was separated from operations and transferred to the newly created Swedish Rail Administration (Banverket) leading to one of the first vertically separated railway markets in the world. In 2001, SJ was split into several state-owned companies: SJ (passenger), Green Cargo (freight), Jernhusen (stations) and Euromaint (maintenance). In 2010, Banverket was integrated with the Swedish Road Administration (Vägverket) to form the Swedish Transport Administration (Trafikverket).

Trafikverket allocates capacity in the Swedish network similarly to many European deregulated markets, see Figure 4 for an overview of the different steps of the capacity allocation. One of the main differences is in the settlement of capacity conflicts that remain after the coordination with applicants which settles most of the capacity conflicts. Unlike many IMs which use simple and general priority lists, Trafikverket uses priority criteria based on cost benefit analysis (CBA) rules aiming to reflect which train path requests that yield the highest social welfare (Trafikverket, 2020). This Swedish CBA-based prioritisation appears to be more developed than the basic rule-of-thumbs criteria that are used for conflict settlement by many European IMs.

Trafikverket uses the CBA-based prioritisation to unilaterally settle the remaining conflicts only if the coordination process fails. Depending on the train category, different weights are used for certain variables such as the scheduled travel distance and time, train connections and cancellation. These weights are estimated using econometric studies to reflect their social welfare effects (Trafikverket, 2016a). 


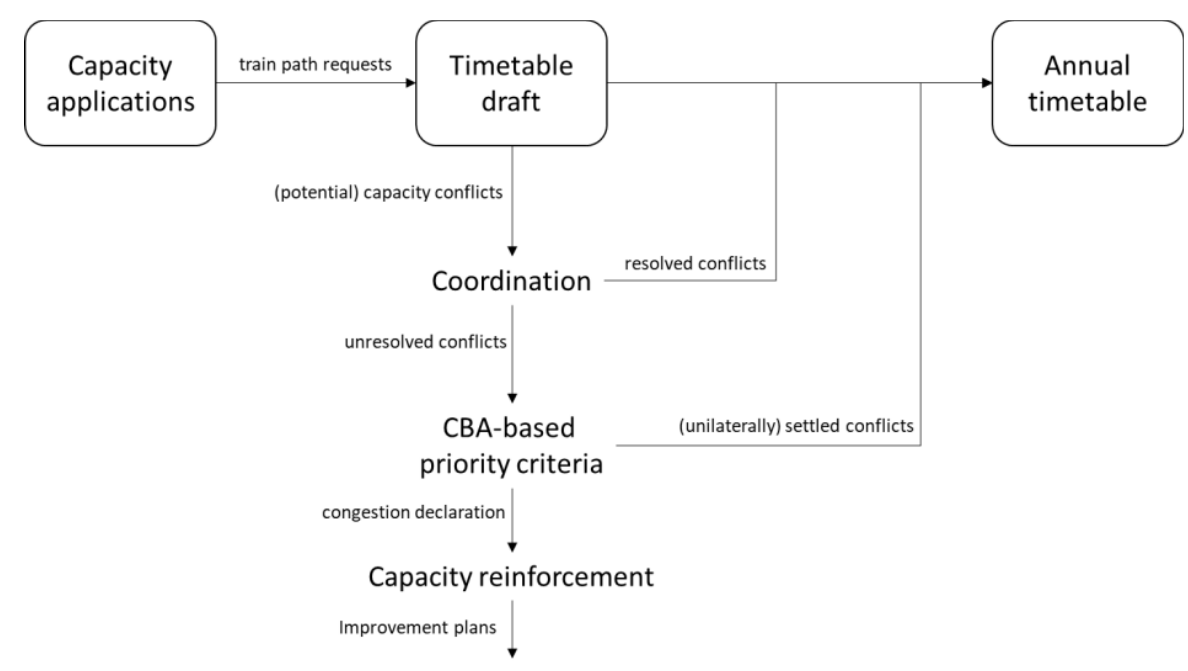

Figure 4. Overview of Swedish railway capacity allocation.

In case of (potential) unfair prioritisation or discrimination, RUs can report complaints and appeal to the regulator, i.e., Swedish Transport Agency (Transportstyrelsen).

\subsection{Existing research and experiments}

The problem of capacity allocation in deregulated markets has been studied extensively in other fields, such as airport slots (Rassenti et al., 1982, Gilbo, 1993), public utilities such as energy (gas and electricity), telecommunications, and water (McMillan, 1994, McAfee and McMillan, 1996). However, few academic works or experiments have been conducted in the railway sector.

Several research papers look at important components to consider for railway capacity allocation such as train timetabling and access charges (Gibson, 2003). Some others discuss the challenges of railway deregulation (Crozet et al., 2012) and the potentials of market-based solutions such as (combinatorial) auction (Nilsson, 2002, Borndörfer et al., 2006, Perennes, 2014). Most studies develop specific algorithms to allocate and/or price railway capacity (Lusby et al., 2011). These studies rarely consider the context of deregulation and the various market segments.

In a doctoral thesis, Pena-Alcaraz (2015) studies the capacity allocation in a deregulated and vertically separated market (called shared railway). The author investigates a capacity allocation solution that combines 
problems of RUs (e.g., train timetabling) and IMs (e.g., capacity pricing), and the market outcome for different pricing strategies. However, no considerations are given to the social welfare in the allocation. These welfare aspects are considered in another doctoral thesis by Perez Herrero (2016) who uses an economic approach to study railway capacity in light of the market deregulation. Although no capacity allocation model is proposed (or studied), the author highlights the use of (optimal) congestion pricing of capacity as an instrument to improve the social welfare of capacity allocation outcomes.

Aspects relating to railway deregulation and capacity allocation have also been the subject of several reports from international organisations and forums. Such reports attempt to summarise and analyse their prospects and challenges. An early publication from OECD (2005) gives a comprehensive summary of the structural reforms that have happened in all the member countries. Focusing on EU countries, Crozet et al. (2012), in a policy report for CERRE, looks at how vertical separation can increase railway efficiency, and identifies key issues and regulatory recommendations for the introduction of competition to the market. This is later discussed by Crozet (2016a) at the International Transport Forum (ITF). Several CERRE follow-up studies deal with more specific aspects such as the liberalisation of passenger rail services in France (Crozet, 2016b), Germany (Link, 2016), Great Britain (Smith, 2016) and Sweden (Nilsson, 2016), or the levying of track access charges in France (Crozet, 2018), Germany (Link, 2018), Sweden (Nilsson, 2018) and Great Britain (Nash et al., 2018).

At the EU level, Train Timetable Redesign (TTR) is an initiative that attempts to redesign the international timetabling process (capacity allocation) in Europe to improve the competitiveness of cross-border (freight) train services. The TTR initiative introduces the concept of rolling planning which allows for ad hoc capacity requests in addition to the traditional annual requests. For instance, it is possible to safeguard bands of train paths (i.e., reserve capacity) and continuously allocate them for freight traffic. Certain pilot lines on cross-border European freight corridors are used for further experimentation (RNE, 2019).

At the national level, Trafikverket initiated a development project for market-adapted planning of capacity in Sweden, locally called MPK. The project aims to create a new (more flexible) approach for railway capacity allocation, and to develop new (digital) supporting tools (Gestrelius et al., 2020). Important contributions include a digital portal for capacity application which allows to access (and manage), for instance, train path 
requests, capacity restrictions and track access charges (Trafikverket, 2016b). The project also attempts to implement the concept of incremental allocation (successiv tilldelning) which was previously studied and presented, e.g., by Aronsson et al. (2012). In such allocation, the annual timetable is initially flexible, and is incrementally constructed starting from (long term) delivery commitments to (more specific) production plans. 



\section{Chapter 3}

\section{Conducted Research}

$$
\text { 'العلم يؤتنى ولاح يأته' }
$$

You have to approach science; it will not come to you Arabic proverb 



\section{Conducted Research}

Following the literature review, this $3^{\text {rd }}$ chapter presents the conducted research. It describes the literature gaps and challenges, and formulates the research questions. A presentation of the research methodology and the developed models follows. Discussion of the conducted research concludes the chapter.

\subsection{Challenges and research gaps}

While studying the Swedish allocation process, Eliasson and Aronsson (2014) show that even the relatively well-developed Swedish conflict resolution model has some flaws. First, CBA calculations rely on certain variables (such as fares, demand, running costs) that are difficult or impossible to observe for commercial train services. For private, commercially driven traffic, such data is highly sensitive business information, and often unknown at the time of capacity allocation. On the other hand, such data is usually available for publicly controlled traffic (e.g., subsidised regional or commuter services). Second, the weights that are used in the CBA-based priority model are static. This means that certain train categories are always prioritised over others leading to so-called corner solutions. Thus, in case no interactions between complementary services exist, the diminishing returns to scale is not captured. In reality, the marginal societal benefit of higher frequency (or shorter headway) on a train service decreases, but this is not captured by the CBA-based priority criteria.

With these challenges in mind, the current CBA-based conflict settlement might lead to inefficient capacity allocation outcomes. Deregulated markets are more prone to capacity conflicts, especially with limited infrastructure capacity and increasing demand. These inefficiencies can therefore intensify in deregulated European markets such as Sweden, and hence the importance of a more efficient (and transparent) capacity allocation and conflict resolution.

Any adjustment to the current capacity allocation should abide by the legislation. On the one hand, EU policies provide guidelines related to capacity allocation and access charges. In Appendix 1: EU directives, the Articles state that conflict settlement can make use of access charges which may be included as an additional charge for scarcity. Such charges can be used to allocate capacity to the most important services to society in a fair and non-discriminatory manner. On the other hand, the Swedish 
legislation (Järnvägslagen) also provides certain general guidelines for allocating infrastructure. In Appendix 2: Swedish railway law, the Clause states that Trafikverket is required to assess the capacity needs of the different types of services (including reserve capacity) and that, in case of unsettled conflicts after the coordination process, it is required to allocate capacity with the help of charges or priority criteria that yield (socioeconomic) efficient utilisation of the infrastructure.

The use of (CBA-based) priority criteria to settle capacity conflicts is generally aligned with the legislation. However, the use of such criteria in deregulated markets faces challenges, e.g., relevant data availability, and may lead to inefficient outcomes which goes against the guidelines. Both European and Swedish legislations allow for using a market-based capacity allocation, i.e., scarcity charges or pricing, an option that has been previously used to allocate capacity, e.g., for airport slots and public utilities. Thus, the lack of models and applications for railway capacity allocation in deregulated markets.

Parts of the conducted research consist of several methods that can help allocate capacity in deregulated markets, e.g., Sweden. Such methods can address many discussed challenges that relate to efficiency and transparency. Moreover, this work helps reduce the described existing gap in the research literature, e.g., capacity allocation and market deregulation in the railway sector.

\subsection{Research questions}

Several challenges and research gaps appear in the light of the literature review. This thesis attempts to answer a number of research questions (RQs) to help address some of the main cited challenges, and to fill in the mentioned research gaps.

To start with, this thesis reviews and analyses existing capacity allocation practices in a number of European railway markets.

RQ1. What capacity allocation is used in current deregulated markets? 
Based on the answers to RQ1, a market-based and transparent capacity allocation is proposed. The focus is on improving the efficiency of existing capacity conflict solutions in important market segments.

RQ2. How can capacity conflicts be more efficiently resolved between commercial and subsidised traffic?

Answering RQ2 requires dealing with a number of other related RQs. First and foremost, capacity conflicts with commercial traffic are solved based on existing conventional CBA guidelines. An efficient capacity conflict resolution (to answer RQ2) therefore relies on the assumption that subsidised traffic supply is efficient according to these guidelines.

RQ3. Is subsidised traffic supply efficient according to CBA guidelines?

A second related RQ focuses on ways to use mathematical optimisation to improve RUs' traffic supply, e.g., train timetables.

RQ4. How can mathematical optimisation be used to further improve the traffic supply?

The third and last related RQ deals with demand data (origin destination or OD matrices), an important input data for more accurate policy decisions, e.g., more efficient traffic supply.

RQ5. How much demand data is needed for more accurate policy decisions?

In the remainder of this thesis, we will present the conducted research, results and contributions to address the presented RQs.

\subsection{Research methodology}

A top-down approach is followed to conduct this research, see Figure 5 for an overview of the components of the methodology and the corresponding included papers. 


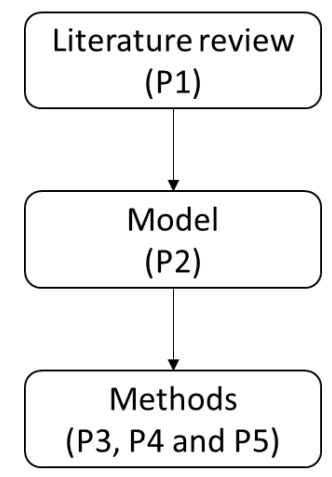

Figure 5. Flowchart of the adopted top-down research methodology.

A survey, in P1, of different European deregulated railway markets focuses on how capacity is currently allocated especially in case of conflicts. Conclusions from the survey, and the study by Eliasson and Aronsson (2014), help identify the need to develop a more efficient capacity allocation model for deregulated markets such as Sweden. The proposed model, in $\mathrm{P} 2$, focuses on allocating capacity in two important market segments, i.e., publicly controlled and commercial traffic.

Thereafter, the conducted research work aims at designing, implementing, and experimenting with several methods to help successively allocate capacity between publicly controlled and commercial traffic. This work includes methods, for instance, to construct efficient train timetables ( $\left.\mathrm{P}_{4}\right)$, to estimate relevant input data such as passenger demand ( $\left.\mathrm{P}_{5}\right)$ and CBA cost parameters $\left(\mathrm{P}_{3}\right)$. More details about these methods are presented later in this chapter.

Various research methods are also adopted at different stages of this work. Table 3 gives an overview of these methods and the corresponding included papers.

Table 3. Research methodology and adopted methods.

\begin{tabular}{llll}
\hline & \multicolumn{3}{l}{ Research methodology } \\
\cline { 2 - 3 } Research methods & Literature & Model & Methods \\
\hline Qualitative text analysis & $\mathrm{P} 1$ & & \\
Cost benefit analysis (CBA) & & $\mathrm{P}_{2}$ & $\mathrm{P}_{3}$ \\
Mathematical programming & & $\mathrm{P} 2$ & $\mathrm{P}_{4}$ and $\mathrm{P}_{5}$ \\
Passenger flow simulation & & $\mathrm{P}$ and $\mathrm{P}_{5}$ \\
Data analysis & $\mathrm{P} 1$ & $\mathrm{P} 2$ & $\mathrm{P}_{3}, \mathrm{P}_{4}$ and $\mathrm{P}_{5}$ \\
\hline
\end{tabular}


Qualitative analysis of official text material (e.g., network statements) is mostly used for the early literature review in P1. Quantitative methods are later used for the allocation model in P2. For instance, CBA is used to assess train timetables in $\mathrm{P}_{3}$, and to price capacity requests in $\mathrm{P}_{2}$. Mathematical programming is applied to model train timetabling in $\mathrm{P}_{4}$ and OD estimation in $\mathrm{P}_{5}$. Methods for passenger flow simulation are useful to assess timetables in $\mathrm{P}_{2}$ and $\mathrm{P}_{3}$, and estimate OD matrices in $\mathrm{P}_{5}$.

Extensive data analysis is used to study and compare different European railways in $\mathrm{P} 1$, and to describe the infrastructure and operations in $\mathrm{P} 2$ using the (microscopic) railway simulation software RailSys (Radtke and Bendfeldt, 2001). Train timetables are exported and manually adjusted to construct train path requests for testing in $\mathrm{P} 2$ and $\mathrm{P} 4$. Moreover, OD estimation methods in $\mathrm{P}_{5}$ use extensive passenger demand data from smart cards. Finally, CBA cost parameters, used in $\mathrm{P}_{2}$ and $\mathrm{P}_{3}$, are based on detailed trip valuation data from national and local guidelines (Trafikverket, 2016a, SLL, 2017).

\subsection{Market-based capacity allocation}

The literature review indicates that countries in Europe are increasingly adopting a deregulated market structure for both passenger and freight traffic. These reforms are driven at the EU level by an attempt to, among other things, stimulate competition. However, the incumbents are often favoured in capacity allocation, and still dominate most markets.

Traditional capacity allocation requires adaptations to best serve the new deregulated markets focusing on transparent and efficient allocation of capacity. Adaptations such as (CBA-based) priority criteria are however not always able to capture the marginal social benefit of certain services, e.g., private-commercial traffic due to limited data availability. The conducted research aims at studying possible improvements to this capacity allocation (presented in Section 2.5) in the light of the cited challenges and issues brought by the deregulation of railway markets, e.g., Sweden. 


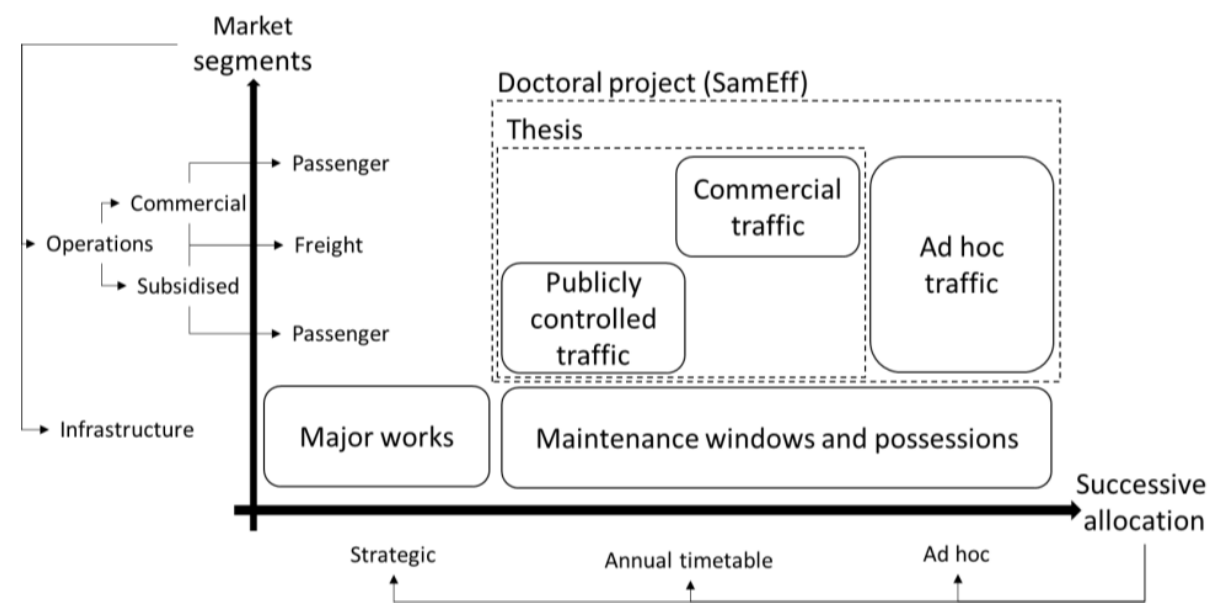

Figure 6. Successive capacity allocation in a segmented market.

For this, we consider a segmented deregulated market, and study successive allocation of capacity over these segments. Figure 6 presents a simplified overview of the allocation of capacity in a segmented deregulated market such as Sweden. The horizontal axis represents the different steps of the allocation whereas the vertical one refers to the market segments. In such successive allocation, capacity is consecutively allocated to different segments, i.e., publicly controlled, then commercial traffic and finally ad hoc requests. Thus, it must not to be confused with incremental allocation (successiv tilldelning), a concept that was previously mentioned in Section 2.6.

Although the boundaries are not always clear, railway markets have several different segments depending, for instance, on the services, funding, and regulations. The main focus of this thesis is on publicly controlled (local or regional commuter) and commercial traffic segments as well as their interactions. Both passenger and freight services are included in the segment for commercial traffic. Interested readers are referred to the study by Froidh and Nelldal (2015) on the different types of traffic supply in Sweden after the deregulation.

Several years before the annual timetable, new infrastructure investments are decided based on government's transport strategic plans. The core step in capacity allocation is the construction of the annual timetable which is the scope of the doctoral project. We distinguish between publicly controlled and commercial traffic since these have different characteristics. On the one hand, publicly controlled (or subsidised) services cover mainly the operation market segment of unprofitable local 
and regional passenger traffic, some trains (e.g., freight postal or passenger night services) can sometimes also be included in this segment but are not studied here. On the other hand, commercial services cover profitable market segments for freight and passenger traffic.

The capacity needed for publicly controlled traffic are applied for by the regional public transport authorities (PTAs or RKTM in Sweden), presumably based on social welfare considerations. Hence, an ideal reference timetable for these regional and local train services should aim for maximising the total societal welfare. Given relevant data, some methods (e.g., in $\mathrm{P}_{3}$ ) in this thesis can be used to achieve that.

For commercial traffic, licensed operators, both state-owned and private, may apply for train paths in the annual timetable. Which train paths (i.e., ideal timetable) to apply for is the results of their business plans which aim at maximising their profit, i.e., revenue minus operation costs. These operators often compete for capacity with each other and with other operators, including PTAs (Alexandersson et al., 2018). In this thesis, we focus on the inter-segment capacity conflicts between publicly controlled and commercial trains. Conflicts between commercial services, although important, fall mainly outside the scope of this thesis. Such conflicts can be resolved with methods such as auction (Affuso, 2003, Perennes, 2014).

The last step is the ad hoc allocation (or short-term planning) of late path requests. One way to allocate these train paths is to use a dynamic pricing (or yield management) scheme. Train paths are priced based on the capacity demand and supply (i.e., reserve capacity). This step is not further explained as it falls slightly outside the scope of this thesis. Such dynamic capacity pricing models are studied by Svedberg (2018), and later by Aronsson (2019) who looks at the overall supply of reserve capacity for ad hoc allocation.

Another important part of the last step, falling outside the scope of the thesis, is the allocation of capacity for infrastructure maintenance. Interested readers are referred to the doctoral thesis by Lidén (2018) for more details on how such capacity can be planned and allocated together with train services.

\subsection{Subsidised traffic}

Local and regional commuter trains are examples of services that are often part of the publicly controlled traffic. In deregulated markets, the 
PTAs are responsible for this type of traffic often through concessions or public service obligation (PSO) contracts with RUs. These contracts are increasingly awarded based on competitive tendering (for-track competition) considering several key performance indicators (KPIs) such as costs, punctuality, sustainability, and innovation. Other special types of contracts also exist but not studied here, e.g., Public Private Partnerships (PPP).

Ideally, the PTA specifies the traffic supply aiming at maximising the societal welfare. That is to say that out of all the possible traffic plans (e.g., frequencies), it chooses the plan yielding the highest societal net welfare. Thereafter, the RU (awarded the contract) should execute the traffic plan in the best possible way under the conditions stated in the contract. An overview of the capacity allocation cycle for publicly controlled traffic is presented in Figure 7 showing the scope of some of the included papers. Note that unlike the less detailed traffic plans (specified by the PTAs), train timetables (operated by the RUs) are more detailed translations of the traffic plan which should additionally consider all the operational constraints (e.g., crew, fleet, network infrastructure) for feasible and safe operations.

The PTAs face the challenging task of specifying a traffic plan that is as efficient as possible in terms of societal welfare. Based on this plan (and contract), the RUs have the (internal) task of finding an operational timetable that is commercially efficient, i.e., economically optimised. There are different ways to do this. The traditional method is to update, often manually, a reference traffic plan (e.g., from last or previous years) based on new information about population growth and urban development, etc. This is often done with the help of expert planners who have accumulated years of experience. 


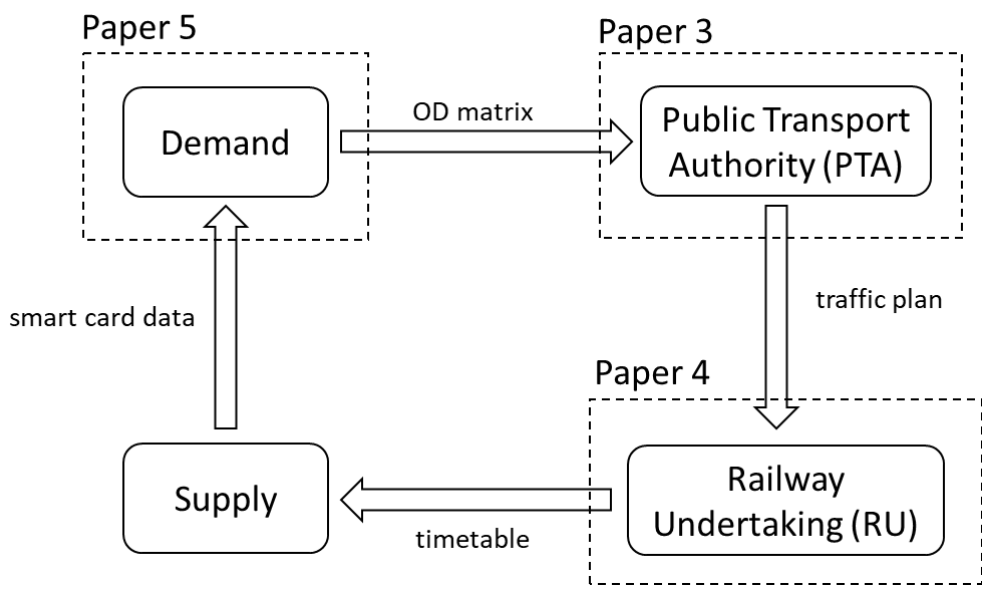

Figure 7. Overview of capacity allocation for publicly controlled traffic.

However, this thesis includes (e.g., in $\mathrm{P}_{3}$ ) a combination of methods from operations research and (micro-)economics to allocate capacity for publicly controlled traffic. In order to study the societal efficiency of a certain traffic plan for a publicly controlled service, CBA methods allow the PTAs to quantify and compare the welfare effects of these plans. Thereafter, timetabling optimisation methods (e.g., mathematical programming and Lagrangian relaxation), such as in $\mathrm{P}_{3}$, can be used to find the optimal plan that the RUs can execute, such as in $\mathrm{P} 4$, under the operational conditions and the infrastructure constraints.

Although not included in this thesis, it is possible to combine the two mentioned steps in one optimisation model, interested readers are referred to the related (i.e., part of the same project) licentiate thesis by Svedberg (2018). However, such train timetabling problems are more complex and thus harder to solve (Svedberg et al., 2015). This thesis contributes thus with models for both steps separately.

Note that the societal efficiency of the traffic plans using CBA requires the availability of relevant data, e.g., passenger demand and operating costs. Such data can be made available in publicly controlled traffic segments, e.g., smart cards as in $\mathrm{P}_{5}$, but not (necessarily) in others such as commercial traffic. 


\subsection{Commercial traffic}

One of the main challenges of allocating capacity in deregulated markets is to, transparently and efficiently, solve capacity conflicts between the different (often competing) applicants. These applicants can be from different market segments, running different or complementary services. In this thesis, we focus on conflicts arising between the commercial (freight or passenger) traffic and the previously discussed publicly controlled ones. A situation which is increasingly common in heterogenous networks such as Sweden's where both types of traffic are steadily growing since the 1990 (Nilsson, 2016).

As discussed earlier, an alternative to the currently widely used priority criteria is a market-based allocation. In this case, it is important to correctly price the infrastructure capacity (i.e., train paths) to reflect marginal societal costs for more efficient capacity allocation outcomes (Perez Herrero, 2016). The capacity is hence allocated based on the prices for train path requests and the applicants' willing-to-pay (WTP).

As an illustration, a case study (from P2) looks at capacity conflicts between publicly controlled Stockholm commuter services and an inter-regional commercial passenger train. The idea is to study the loss in societal welfare for commuter services when scheduling the commercial train path. Figure 8 presents different rescheduling scenarios to solve capacity conflicts.

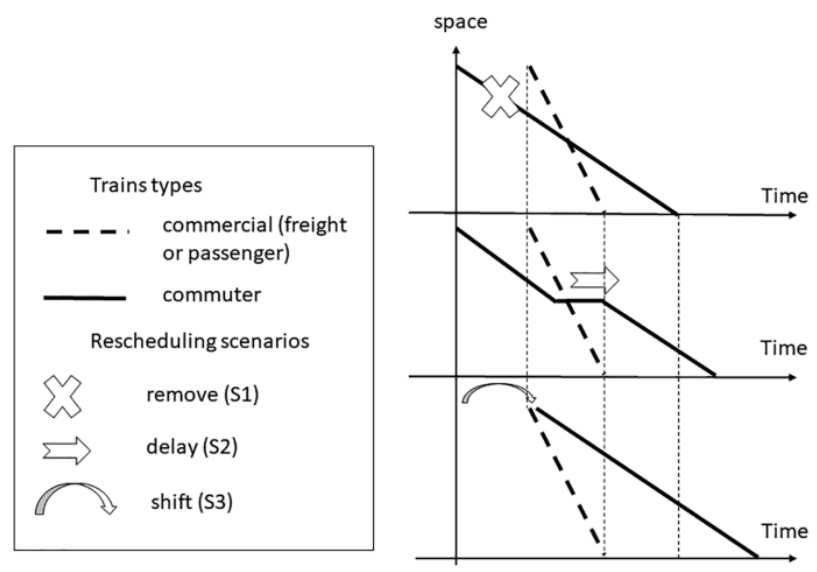

Figure 8. Illustration of different train path adjustments. 
For different time periods of a typical working day, Figure 9 presents the prices of the commercial train paths. Such prices change significantly depending on the time (peak or off-peak) and/or the rescheduling scenario (how train path requests are adjusted). An important assumption in this case study is that the reference commuter timetable is optimal, i.e., yields maximal total societal welfare. Thus, any rescheduling of this timetable will generate a loss in the total societal welfare, i.e., non-negative price for the commercial train path.

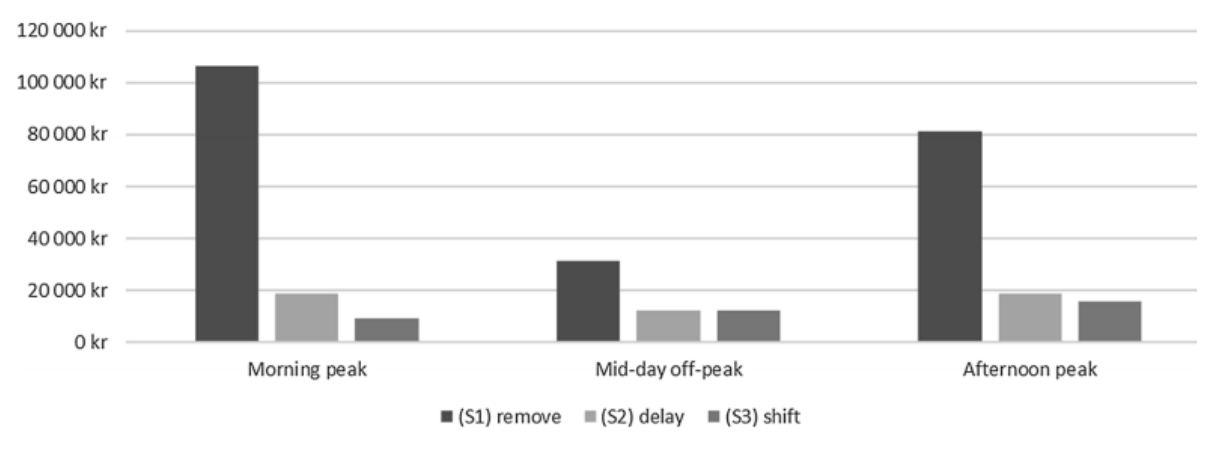

Figure 9. Example of commercial train path pricing (in SEK).

The price for commercial train paths is based on the marginal loss of total societal welfare for publicly controlled traffic. It serves as a reservation price for the path to be allocated. However, some paths can be requested by more than one applicant (e.g., in open access lines). In this case, the price can be used as an initial reservation price in an auction process between these applicants (Kuo and Miller-Hooks, 2015, Stojadinović et al., 2019).

\subsection{Discussion}

Several methods for allocating capacity in deregulated railway markets are previously briefly discussed. Further discussion of the conducted research is presented in this section.

Railways have high initial investment costs, for instance, to acquire the necessary rolling stock (Murillo-Hoyos et al., 2016). This can become a substantial economic burden and barrier to entry, especially for potential new entrants, often in need for several years to become profitable. Such considerations are not modelled in this thesis, however, one way to mitigate these entry barriers is the allocation of capacity over multiple years, also called traffic agreements (RNE, 2017). An additional solution 
consists in setting up (state-owned) leasing companies assuming the ownership of the rolling stock.

An important issue relates to information asymmetry. In reality, the incumbent(s) in some railways may have substantial information advantage in the market compared to new entrants. In addition, the presence of cross-subsidisation may further magnify this advantage. Such market imperfections (or distortions) often lead to inefficient market outcomes. In this case, the regulators should intervene to ensure, for instance, transparent access to information, ticket sales channels and fair access charges for the new entrants. However, these asymmetric regulations, in favour of new entrants (on the expense of the incumbent), can threaten interoperability, e.g., within the harmonised SERA markets (Montero, 2019).

Another important issue is data quality and availability, both are assumed for most of the presented methods. For instance, demand data is used to calculate the loss in the total societal welfare for publicly controlled traffic which is in turn used to price commercial train paths. Better data quality is therefore important for a more efficient capacity pricing and allocation. However, this requires, among others, the development of suitable infrastructure for information and communications technologies (ICTs), e.g., through digitalisation. In this context, cybersecurity should be as important for safety as infrastructure maintenance.

Different types of congestion are mentioned in the conducted research. On the one hand, capacity congestions (on the track) are used to motivate the need for capacity allocation. These occur when the IM rejects train paths requests from one or more RUs due to capacity shortage, i.e., the capacity constraints (as in $\mathrm{P} 4$ ) are binding, and the corresponding multipliers (or shadow prices) can be interpreted as the marginal value of increased capacity, e.g., useful for planning future infrastructure investments. On the other hand, the cost functions (in $\mathrm{P}_{2}$ and $\mathrm{P}_{3}$ ) accounts for in-vehicle congestion costs as part of the consumer surplus (for subsidised passenger traffic). Such congestion is incurred by train passengers in the form of an increased perceived travel time (or sometimes denied boarding). With these two congestion perspectives in mind, it is important to incentivise RUs to efficiently use allocated train paths together with their rolling stock (e.g., number of wagons and train formation) in order to reduce both capacity and in-vehicle congestion.

As mentioned before, apart from the subsidised versus commercial traffic, other types also exist in different deregulated railways. For instance, 
some RUs can be subsidised (for welfare maximisation), and at the same time be allowed to provide commercial traffic (and maximise profit). Another example is when PTA's traffic goes beyond the boundaries of the region, and thus compete with other regional subsidised or commercial services. There are multiple examples of such situations (in Sweden), and often require ad hoc solutions between the stakeholders, e.g., agreements between PTAs and/or RUs. Thus, these situations have not been studied in this thesis. Interested readers are referred to the study by Alexandersson et al. (2018) on such situations around the greater Stockholm region in Sweden.

Besides, political considerations can undermine the efficiency and transparency of the capacity allocation. One can suspect that grandfather rights and political lobbying are factors that may affect capacity allocation, although such practices are illegal and not allowed to affect capacity allocation decisions by the IM (Gestrelius et al., 2020). Another related issue that needs to be addressed is equity in the supply and accessibility of transport services (Rubensson, 2019). Finally, transferring profits abroad by foreign RUs should also be highlighted as these benefits are exported, i.e., not accounted for in the national gross domestic product (GDP).

Differentiation exists already in certain track access charges, e.g., passage or emission charges (Nilsson, 2018). However, the introduction of a demand-responsive market-based pricing can face resistance before being gradually accepted, e.g., road congestion pricing in Stockholm (Eliasson, 2008). Such resistance would come from the different stakeholders such as commercial freight and passenger RUs. Ways to soften the transition exist, e.g., gradual implementation through further developments and prototyping with the different proposed methods. One possible experiment is to use gamification, i.e., capacity allocation as a game between the different stakeholders (Meijer, 2015). Other more practical experiments could be conducted on specific national corridors as with several freight corridors in the TTR project (RNE, 2019).

Finally, European and national legislations do not seem to be ahead of the developments in the railway market, especially when it comes to capacity allocation, and how it should be implemented in deregulated markets. Thus, legal grounds need to be clarified and developed ahead of the new developments, e.g., (market-based) capacity allocation. 



\section{Chapter 4}

\section{Contributions \& Future Works}

'C'est par la logique qu'on démontre, c'est par l'intuition qu'on invente'

It is by logic that we prove, but by intuition that we discover Henri Poincaré, French polymath 



\section{Contributions and Future Works}

This $4^{\text {th }}$ chapter provides a summary for each included paper. It describes the papers' contributions to answer the corresponding research questions. The chapter ends with conclusions and insights for future works.

\subsection{Summary of the papers}

\section{Summary of P1}

\section{A Survey of Railway Deregulation in Europe.}

This review paper describes the railway deregulation in Europe by studying market organisation in several selected countries. It focuses mostly on deregulated markets which underwent major reforms following a number of EU directives (EC, 1991, EC, 2001, EC, 2012). These reforms introduced new market structures and more importantly new challenges for capacity allocation. One of the goals of these reforms is to introduce (or increase) competition, both for passenger and freight services. Thus, the need for capacity allocation that is transparent from a procedural perspective, clear and non-discriminatory. Such allocation also needs to be efficient from a market perspective, ensuring the best societal value.

The paper reviews aspects related to capacity allocation such as solving capacity conflicts on markets where several operators exist and compete for capacity. For each selected country, an extensive desk survey reviews a brief history of the market, existing actors, resolution of capacity conflicts and principles for calculating access charges, if any.

Based on the review, few if any countries use capacity allocation methods that are transparent and efficient. As to transparency, it is difficult for outsiders or new entrants, to understand the priority criteria (often second-best solutions) when capacity conflicts occur. Moreover, the actor responsible for capacity allocation (the IM) is sometimes related to the incumbent (often dominant) RU, and new entrants have reasonable concerns for discrimination in the market. As to efficiency, such aspects are rarely considered in the allocation even if the purpose of a competitive market is to ensure, in the long run, that train services which give the best value for money to consumers should get priority in allocating capacity, especially in case of conflicts. However, the 
review indicates that efficiency considerations are surprisingly almost absent. Priority criteria have (at best) a vague relation to consumer demand and market efficiency. A vast majority of priority criteria and decision rules instead relates to simple administrative or technical criteria, e.g., longer train paths, passenger services over freight services, and timetable robustness.

The survey shows that most countries still have some way to go in opening the market for competition and benefiting from it. In particular, rules for allocating capacity need to be more transparent (from a procedural perspective) and more efficient (from a societal perspective).

\section{Summary of P2}

\section{Pricing Commercial Train Path Requests Based on Societal Costs.}

The paper describes how commercial train path requests can be priced based on societal costs. It considers the case where the railway market is deregulated. Inevitably, capacity conflicts arise, and in such cases the IM needs to prioritise between conflicting path requests. Depending on the ownership of the infrastructure, the IM can have different objectives. One of these is to allocate capacity in a way that maximises total societal benefits. The paper describes an approach to resolve conflicting capacity requests between commercial trains (maximising profit) and publicly controlled traffic (maximising welfare).

The model presented in this paper allows to calculate the societal costs (i.e., loss in social welfare) caused by changing the commuter train timetable to accommodate the commercial train path. Such costs include in-vehicle and waiting times, transfers, (in-vehicle) crowding and operating costs, and are used to price the commercial train path. The societal costs (or train path prices) are calculated using origin destination matrices (based on smart card data, studied in more details in $\mathrm{P}_{5}$ and $\mathrm{RP}_{3}$ ), time valuations (e.g., value of travel time and waiting time, the latter is studied in more details in $\mathrm{P}_{3}$ ) and parameters for operating costs.

The railway network in Stockholm is used as the case study. The results show that accommodating additional train paths in the busy commuter timetable comes at a high societal cost - much higher than the current charges (called passageavgift or passing fees) intended to partly reflect scarce capacity in transport hubs such as Stockholm. We also show that it is possible to substantially reduce the costs of 
changes in commuter train timetables by choosing the best rescheduling alternative.

The main contribution of this paper is a method to calculate a reservation price for a commercial train path request by estimating the societal costs (i.e., loss of benefits) of the changes needed in a baseline commuter train timetable to accommodate this path request. If the commercial operator is willing to pay this reservation price, it is awarded the path and the commuter train timetable is adjusted; if not, the request is declined, and the commuter trains are given priority.

\section{Summary of P3}

Are Commuter Train Timetables Consistent with Passengers'Valuations of Waiting Times and In-vehicle Crowding?

This paper is an attempt to check if commuter train timetables are consistent with valuations of certain trip parameters such as waiting time and in-vehicle crowding that are estimated from passenger preferences and used in CBA. It is a follow-up study to P2 where such consistency is assumed, i.e., subsidised traffic supply is efficient according to CBA guidelines. Thus, this study compares passengers' valuations (i.e., traveller perspective) with the ones implied by the service frequencies in the PTA's traffic plan for commuting services (i.e., government's perspective).

Stockholm's commuter train services (pendeltåg) are used as a case study to compare the societally optimal and SL's actual frequencies where SL (Storstockholms Lokaltrafik) is the PTA in the region of Stockholm. Such comparison allows to estimate SL implicit valuations of the studied trip parameters (i.e., waiting time and crowding). Using an analytic CBA model, similar to the one presented in P2, this paper is a numerical study of the optimal frequency (or headway) on certain highly frequented lines. The results suggest that SL's timetables are not quite consistent with passengers' valuations.

In order to explain this inconsistency, i.e., SL frequencies being slightly higher than optimal, this study further estimates SL implicit valuation. For instance, these valuations for waiting times are found to be twice as high as the ones used in CBA guidelines, which are often estimated based on passenger (stated or revealed) preferences. Moreover, we find that the optimal frequencies are more sensitive to the waiting time 
valuation than to that of crowding, implying lower levels of crowding if trains are assumed to be punctual (or robust timetables).

Even if the presented results remain inconclusive, due to different assumptions (e.g., no delays, frequency granularity and fixed operating costs), the work in this study provides an example of models that can be used by PTAs for more efficient (and transparent) allocation of capacity, especially if such capacity is shared with other subsidised and/or commercial services in a deregulated railway market.

\section{Summary of $\mathrm{P}_{4}$}

A disaggregate bundle method for train timetabling problems.

P4 studies the train timetabling problem (TTP) which refers to finding a feasible train timetable minimising a certain objective function. TTP is difficult to solve using the-state-of-art optimisation algorithms in a tractable period of time since it is NP-hard (Caprara et al., 2002). Therefore, solving the TTP often means finding a good quality solution within a given period of computation time.

This paper studies the existing TTP model by Brännlund et al. (1998), discretised in time and space, and formulated as a mathematical program, more specifically Integer Programs (IP). Alternative formulations exist such as Mixed Integer Programs (MIP), mostly used for continuous models in time and/or space (Forsgren et al., 2013).

The study derives an alternative solution method using lagrangian relaxation, called disaggregate bundle method, and compares its computational performances with the (standard) aggregate method, also used by Brännlund et al. (1998). The comparison is based on a real-world timetabling scenario from the Iron Ore line (Malmbanan) in Northern Sweden.

Numerical results indicate that the proposed solution method tends to give shorter execution times compared to the existing standard method. Moreover, the disaggregate method generates larger sets of possible train paths, a useful feature for constructing better feasible timetables.

Additional outputs also include optimal shadow prices (or multipliers), useful for analysing capacity scarcity in space and time, and for calculating the marginal value of new infrastructure (or maintenance) 
investments. Hence, this study shows that the proposed approach has the potential to improve lagrangian-based solution methods for solving the TTP.

\section{Summary of P5}

The Value of Additional Data for Public Transport Origin-Destination Matrix Estimation.

With the increasing amount of data, generated from public transport (PT) systems such as smart cards, this final paper focuses on (dynamic) OD estimation in a railway PT network. The aim is to study the value of additional PT data when used for the estimation in an entry-only network, i.e., only the origin counts are known (from smart cards).

Using the principle of entropy maximisation (EM), the study compares the estimation quality or relative root mean square error (RMSE), when combinations of different data types are known and used for estimating the dynamic OD matrix. The RMSE of two policyrelevant estimated outputs are studied, namely the flows at exit stations and at links. Combinations of data types such as the number of alighters, average travel distance and certain link flows are valuated and compared for different time periods of the day (i.e., morning and afternoon peak hours, and midday off-peak).

The study uses extensive travel demand data (e.g., based on smart cards) from the Piccadilly line in London. The results indicate that, although inexpensive, certain data can be more valuable and considerably improve the quality of the estimation compared to more expensive and detailed data. The marginal value of such detailed additional data may be lower, especially when other data is already used in the estimation. Such results are inconclusive, and require further validation using, for instance, other estimation models, error metrics and additional data sources in other case studies.

\subsection{Main contributions}

In order to answer the research questions, the thesis has several main contributions which we present in this section.

RQ1. What capacity allocation is used in current deregulated markets? 
C1. Overview of deregulated railway markets in Europe: Capacity allocation aspects are reviewed in [P1]. With focus on European deregulated markets, the paper provides details on the current legislation, organisation, competition, capacity allocation and track access charges.

RQ2. How can capacity conflicts be more efficiently resolved between commercial and subsidised traffic?

C2. Currently used ways to solve capacity conflicts:

Focusing on European deregulated markets, [P1] reviews existing ways to solve capacity conflicts, and analyses their (dis-)advantages.

C3. Pricing commercial train paths using marginal societal costs:

[P2] describes a more efficient market-based allocation where commercial train path requests are priced based on their marginal societal costs on commuter traffic.

RQ3. Is subsidised traffic supply efficient according to CBA guidelines?

C4. Assessment of societal costs for commuter traffic:

Based on existing CBA guidelines, [P2] presents a method to calculate the societal costs of changes in the subsidised commuter traffic.

C5. PTA's implicit valuation for waiting time and crowding:

By comparing the current (PTA's) and optimal traffic supply, [P3] shows how PTA's implicit valuation for waiting and in-vehicle crowding can be inferred.

RQ4. How can mathematical optimisation be used to further improve the traffic supply?

C6. Optimal frequencies for commuter traffic:

In the absence of a closed form for the optimum, [P3] uses simulationbased optimisation to find the numerical values of the optimal frequencies for commuter traffic.

C7. Improved method to solve lagrangian-based TTP models:

As a first step to solve the TTP, [P4] studies an improved variant of bundle methods (called disaggregate) to find good quality solutions for the (relaxed) timetabling optimisation problem. 
C8. EM-based estimation models for dynamic OD matrices:

An important input data to improve (passenger) traffic supply is the dynamic OD matrix. In [P5], an EM-based estimation model is presented and used to find dynamic OD matrices based on smart card and additional data.

RQ5. How much demand data is needed for more accurate policy decisions?

C9. Optimal traffic supply based on OD data:

[P3] shows how dynamic OD data can be used to make more accurate policy decisions regarding commuter traffic supply.

C10. Value of additional data for better dynamic OD estimates:

More accurate policy decisions are based on more accurate OD estimates. [P5] shows that certain additional data can substantially improve the accuracy of dynamic OD estimates.

These contributions are of interest to different stakeholders within the railway market. Table 4 provides a mapping of the main contributions, the papers, and the main stakeholders with examples from Sweden.

Table 4. Main contributions and interested stakeholder(s).

\begin{tabular}{|c|c|c|c|c|c|c|c|c|c|c|}
\hline \multirow{2}{*}{$\begin{array}{l}\text { Stakeholder } \\
\text { (Sweden) }\end{array}$} & \multirow{2}{*}{$\begin{array}{l}\text { RQ1 } \\
\text { C1 }\end{array}$} & \multicolumn{2}{|c|}{ RQ2 } & \multicolumn{2}{|c|}{ RQ3 } & \multicolumn{2}{|c|}{ RQ4 } & \multicolumn{3}{|c|}{ RQ5 } \\
\hline & & C2 & C3 & $\mathbf{C 4}$ & $\mathrm{C}_{5}$ & C6 & $\mathbf{C}_{7}$ & $\mathrm{C8}$ & C9 & C10 \\
\hline $\begin{array}{l}\text { Regulator (Trans- } \\
\text { portstyrelsen) }\end{array}$ & $\mathrm{P} 1$ & P1 & & & & & & & & \\
\hline IM (Trafikverket) & $\mathrm{P} 1$ & $\mathrm{P} 1$ & $\mathrm{P} 2$ & $\mathrm{P} 2$ & & & $\mathrm{P}_{4}$ & & & \\
\hline PTA (SL) & & & & $\mathrm{P} 2$ & $\mathrm{P}_{3}$ & $\mathrm{P}_{3}$ & & $\mathrm{P}_{5}$ & $\mathrm{P}_{3}$ & $\mathrm{P}_{5}$ \\
\hline $\mathrm{RU}(\mathrm{SJ})$ & & & & & & & $\mathrm{P}_{4}$ & $\mathrm{P}_{5}$ & $\mathrm{P}_{3}$ & $\mathrm{P}_{5}$ \\
\hline RU (Green Cargo) & & & & & & & $\mathrm{P}_{4}$ & & & \\
\hline
\end{tabular}

\subsection{Conclusions and future works}

Deregulation of railway markets brought new issues and challenges to capacity allocation. This thesis deals with the problem of how to efficiently and transparently allocate available railway capacity to different competing applicants. For that, we present methods to successively allocate capacity in a segmented market.

The contributions of this thesis focus on CBA solutions that allow PTAs to efficiently create traffic plans for publicly controlled traffic. For the 
IM, pricing train paths are studied to solve capacity conflicts and allocate capacity for commercial traffic. Moreover, various methods are developed for other stakeholders, e.g., data collection and train timetabling.

The case studies indicate that the proposed solutions have an important potential to be integrated in future capacity allocations, especially with the increasing scarcity in capacity. However, experimentation and prototyping are still needed. These can help address further concerns such as data, legislation and acceptability.

Future research work can build upon the methods presented in this thesis to develop and implement solutions for other segments such as infrastructure maintenance and ad hoc allocation (e.g., reserve capacity and real time traffic management). Other future works may also include further testing of the proposed solutions. For instance, gamification of the allocation process or more practical pilot projects on specific national corridors (as in the TTR initiative) can reveal further relevant insights. Such future works can also investigate digitalisation strategies, and look at how the legislation can be in line with the new developments. 


\section{References}

ABBOTT, M. \& COHEN, B. 2017. Vertical integration, separation in the rail industry: a survey of empirical studies on efficiency. European Journal of Transport and Infrastructure Research, 17, 207-224.

ABRIL, M., BARBER, F., INGOLOTTI, L., SALIDO, M. A., TORMOS, P. \& LOVA, A. 2008. An assessment of railway capacity. Transportation Research Part ELogistics and Transportation Review, 44, 774-806.

AFFUSO, L. 2003. Auctions of rail capacity? Utilities Policy, 11, 43-46.

AIT-ALI, A. \& ELIASSON, J. 2019. Dynamic Origin-Destination Estimation Using Smart Card Data: An Entropy Maximisation Approach. Preprint arXiv:1909.02826.

AIT-ALI, A., ELIASSON, J. \& WARG, J. Measuring the Socio-economic Benefits of Train Timetables Application to Commuter Train Services in Stockholm. 20th EURO Working Group on Transportation Meeting, EWGT 2017, 2017 Budapest. 849-856.

AIT-ALI, A., LINDBERG, P. O., ELIASSON, J., NILSSON, J.-E. \& PETERSON, A. 2020a. A disaggregate bundle method for train timetabling problems. Journal of Rail Transport Planning \& Management, 100200.

AIT-ALI, A., WARG, J. \& ELIASSON, J. 2020b. Pricing commercial train path requests based on societal costs. Transportation Research Part A: Policy and Practice, 132, 452-464.

ALEXANDERSSON, G., BONDEMARK, A., HENRIKSSON, L. \& HULTÉN, S. 2018. Coopetition between commercial and subsidized railway services - The case of the greater Stockholm region. Research in Transportation Economics, 69, 349-359.

ALEXANDERSSON, G. \& RIGAS, K. 2013. Rail liberalisation in Sweden. Policy development in a European context. Research in Transportation Business \& Management, 6, 88-98.

ANDERSSON, E. V., PETERSON, A. \& TÖRNQUIST KRASEMANN, J. 2013. Quantifying railway timetable robustness in critical points. Journal of Rail Transport Planning \& Management, 3, 95-110.

ARONSSON, M. 2019. Reservkapacitet i tågplaneprocessen : Förstudie. RISE Rapport.

ARONSSON, M., FORSGREN, M. \& GESTRELIUS, S. The Road to Incremental Allocation \& Incremental Planning Content and Potential. 2012.

BORNDÖRFER, R., GRÖTSCHEL, M., LUKAC, S., MITUSCH, K., SCHLECHTE, T., SCHULTZ, S. \& TANNER, A. 2006. An Auctioning Approach to Railway Slot Allocation. Competition and Regulation in Network Industries, 1, 163-196.

BOUF, D., CROZET, Y. \& LÉVÊQUE, J. Vertical separation, disputes resolution and competition in railway industry. Thredbo 9, 9th conference on competition and ownership in land transport, 5-9 september 2005, Lisbonne., 2005 Lisbon Lisbon Technical University, 14 p.

BROMAN, E. \& ELIASSON, J. 2019. Welfare effects of open access competition on railway markets. Transportation Research Part A: Policy and Practice, 129, 72-91.

BRÄNNLUND, U., LINDBERG, P. O., NÕU, A. \& NILSSON, J.-E. 1998. Railway Timetabling using Lagrangian Relaxation. Transportation Science, 32, 358369.

CAPRARA, A., FISCHETTI, M. \& TOTH, P. 2002. Modeling and solving the train timetabling problem. Operations Research, 50, 851-861. 
CROZET, Y. 2016a. Introducing competition in the European rail sector. Discussion Paper prepared for the Roundtable on Assessing regulatory changes in the transport sector.

CROZET, Y. 2016b. Liberalisatin of passenger rail services - France.

CROZET, Y. 2018. Case Study - France: logic and limits of full cost coverage. In: CERRE (ed.) Track access charges: reconciling conflicting objectives. CERRE \& University of Lyon (LAET).

CROZET, Y., NASH, C. \& PRESTON, J. 2012. Beyond the quiet life of a natural monopoly: Regulatory challenges ahead for Europe's rail sector. Policy paper, CERRE, Brussels, December, 24.

DE PALMA, A. \& MONARDO, J. 2019. Natural Monopoly in Transport.

EC 1991. Council Directive 91/440/EEC of 29 July 1991 on the development of the Community's railways. European Commission.

EC 2001. Directive 2001/14/EC on the allocation of railway infrastructure capacity and the levying of charges for the use of railway infrastructure and safety certification. EU Parliament.

EC 2012. Directive 2012/34/EU on establishing a single European railway area. EU Parliament.

EC 2016. Fourth railway package of 2016. European Commission.

ELIASSON, J. 2008. Lessons from the Stockholm congestion charging trial. Transport policy, 15, 395-404.

ELIASSON, J. \& ARONSSON, M. 2014. Samhällsekonomiskt effektiv tilldelning av järnvägskapacitet: några synpunkter på Trafikverkets nuvarande process. Working papers in Transport Economics. CTS - Centre for Transport Studies Stockholm (KTH and VTI).

FORSGREN, M. 2003. Computation of Capacity on railway Networks. SICS Research Report.

FORSGREN, M., ARONSSON, M. \& GESTRELIUS, S. 2013. Maintaining tracks and traffic flow at the same time. Journal of Rail Transport Planning \& Management, 3, 111-123.

FREEBAIRN, J. 1998. Access prices for rail infrastructure. Economic Record, 74, 286-296.

FROIDH, O. \& NELLDAL, B. L. 2015. The impact of market opening on the supply of interregional train services. Journal of Transport Geography, 46, 189-200.

GESTRELIUS, S., PETERSON, A. \& ARONSSON, M. 2020. Timetable quality from the perspective of a railway infrastructure manager in a deregulated market: An interview study with Swedish practitioners. Journal of Rail Transport Planning \& Management, 100202.

GIBSON, S. 2003. Allocation of capacity in the rail industry. Utilities Policy, 11, 3942.

GILBO, E. P. 1993. Airport capacity: representation, estimation, optimization. IEEE Transactions on Control Systems Technology, 1, 144-154.

GOVERDE, R. M. P. \& HANSEN, I. A. Performance indicators for railway timetables. 2013 IEEE International Conference on Intelligent Rail Transportation Proceedings, 30 Aug.-1 Sept. 2013 2013. 301-306.

HANSSON, L. \& NILSSON, J. E. 1991. A new Swedish railroad policy: Separation of infrastructure and traffic production. Transportation Research Part aPolicy and Practice, 25, 153-159.

JENSEN, A. \& STELLING, P. 2007. Economic impacts of Swedish railway deregulation: A longitudinal study. Transportation Research Part ELogistics and Transportation Review, 43, 516-534. 
KUO, A. \& MILLER-HOOKS, E. 2015. Combinatorial auctions of railway track capacity in vertically separated freight transport markets. Journal of Rail Transport Planning \& Management, 5, 1-11.

LAURINO, A., RAMELLA, F. \& BERIA, P. 2015. The economic regulation of railway networks: A worldwide survey. Transportation Research Part A: Policy and Practice, 77, 202-212.

LIDÉN, T. 2018. Concurrent planning of railway maintenance windows and train services. Doctoral thesis, comprehensive summary, Linköping University Electronic Press.

LINK, H. 2016. Liberalisatin of passenger rail services - Germany.

LINK, H. 2018. Case Study - Germany. In: CERRE (ed.) Track access charges: reconciling conflicting objectives. German Institute for Economic Research (DIW Berlin).

LUSBY, R. M., LARSEN, J., EHRGOTT, M. \& RYAN, D. 2011. Railway track allocation: models and methods. OR Spectrum, 33, 843-883.

MCAFEE, R. P. \& MCMILLAN, J. 1996. Analyzing the Airwaves Auction. Journal of Economic Perspectives, 10, 159-175.

MCMILLAN, J. 1994. Selling Spectrum Rights. Journal of Economic Perspectives, 8, 145-162.

MEIJER, S. 2015. The Power of Sponges: Comparing High-Tech and Low-Tech Gaming for Innovation. Simulation \& Gaming, 46, 512-535.

MERKERT, R. 2012. An empirical study on the transaction sector within rail firms. Transportmetrica, 8, 1-16.

MERKERT, R. \& NASH, C. A. 2013. Investigating European railway managers' perception of transaction costs at the train operation/infrastructure interface. Transportation Research Part a-Policy and Practice, 54, 14-25.

MIZUTANI, F., SMITH, A., NASH, C. \& URANISHI, S. 2015. Comparing the Costs of Vertical Separation, Integration, and Intermediate Organisational Structures in European and East Asian Railways. Journal of Transport Economics and Policy, 49, 496-515.

MONAMI, E. 2000. European passenger rail reforms: A comparative assessment of the emerging models. Transport Reviews, 20, 91-112.

MONTERO, J. J. 2019. Asymmetric regulation for competition in European railways? Competition and Regulation in Network Industries, 20, 184-201.

MURILLO-HOYOS, J., VOLOVSKI, M. \& LABI, S. 2016. Rolling stock purchase cost for rail and road public transportation: random-parameter modelling and marginal effect analysis. Transportmetrica A: Transport Science, 12, 436457.

$\mathrm{NASH}, \mathrm{C}$. 2008. Passenger railway reform in the last 20 years - European experience reconsidered. Reforms in Public Transport, 22, 61-70.

NASH, C., CROZET, Y., LINK, H., NILSSON, J.-E. \& SMITH, A. 2018. Track access charges: reconciling conflicting objectives - project report. In: CERRE (ed.). CERRE.

NASH, C. A., SMITH, A. S. J., VAN DE VELDE, D., MIZUTANI, F. \& URANISHI, S. 2014. Structural reforms in the railways: Incentive misalignment and cost implications. Research in Transportation Economics, 48, 16-23.

NILSSON, J.-E. 2002. Towards a welfare enhancing process to manage railway infrastructure access. Transportation Research Part A, 36, 419-436.

NILSSON, J.-E. 2016. Liberalisation of passenger rail services - Sweden.

NILSSON, J. E. 2018. Case Study - Sweden: Track access charges and the implementation of the SERA directive - promoting efficient use of railway infrastructure or not? In: CERRE (ed.) Track access charges: reconciling 
conflicting objectives. VTI Swedish National Road and Transport Research Institute.

OECD 2005. Structural Reform in the Rail Industry. Competition Policy Roundtables.

PENA-ALCARAZ, M. M. T. 2015. Analysis of Capacity Pricing and Allocation Mechanisms in Shared Railway Systems. PhD, MIT - Massachusetts Institute of Technology.

PERENNES, P. 2014. Use of combinatorial auctions in the railway industry: Can the "invisible hand" draw the railway timetable? Transportation Research Part A: Policy and Practice, 67, 175-187.

PEREZ HERRERO, M. 2016. Rail capacity constraints : an economic approach. $\mathrm{PhD}$, Université Lumière Lyon 2.

PETERSEN, E. R. 1974. Over the road transit time for a single track railway. Transportation Science, 8, 65-74.

RADTKE, A. \& BENDFELDT, J. Handling of railway operation problems with RailSys. Proceedings of the $5^{\text {th }}$ world congress on rail research. , 2001 Cologne.

RASSENTI, S. J., SMITH, V. L. \& BULFIN, R. L. 1982. A Combinatorial Auction Mechanism for Airport Time Slot Allocation. The Bell Journal of Economics, $13,402-417$.

RIKSDAG. 2004. Järnvägslag [Online]. Infrastrukturdepartementet Available: https://www.riksdagen.se/sv/dokument-lagar/dokument/svenskforfattningssamling/jarnvagslag-2004519_sfs-2004-519 [Accessed 2019].

RIKSTERMBANKEN. 2019. Sweden's National Term Bank [Online]. Available: http://www.rikstermbanken.se/ [Accessed 2019].

RNE 2017. Glossary of Terms Related to Network Statements. 7 ed.

RNE. 2019. TTR General Introduction [Online]. Available: http://ttr.rne.eu/general/general-introduction/ [Accessed 2019].

RUBENSSON, I. 2019. Making Equity in Public Transport Count. Doctoral thesis, comprehensive summary, KTH Royal Institute of Technology.

SLL 2017. Dokumentation av SAMS 3.0. Stockholm.

SMITH, A. 2016. Liberalisatin of passenger rail services - Britain.

STOJADINOVIĆ, N., BOŠKOVIĆ, B., TRIFUNOVIĆ, D. \& JANKOVIĆ, S. 2019. Train path congestion management: Using hybrid auctions for decentralized railway capacity allocation. Transportation Research Part A: Policy and Practice, 129, 123-139.

SVEDBERG, V. 2018. Towards optimal railway track utilization based on societal benefit. Licentiate thesis, monograph, Linköping University Electronic Press.

SVEDBERG, V., ARONSSON, M. \& JOBORN, M. Timetabling based on generalised cost. 2015 .

TRAFIKVERKET 2016a. English summary of ASEK recommendations.

TRAFIKVERKET. 2016b. Market-adapted planning of capacity (MPK) - approaches and tools for the future [Online]. Available: https://www.trafikverket.se/en/startpage/operations/Operationsrailway/improved-capacity/market-adapted-planning-of-capacity-mpk--approaches-and-tools-for-the-future/ [Accessed 2020].

TRAFIKVERKET 2020. Network Statement 2021. Swedish Transport Administration.

UIC 2004. UIC Code 406 - Capacity. In: RAILWAYS, I. U. O. (ed.).

VAN WEE, B., ANNEMA, J. A. \& BANISTER, D. 2013. The transport system and transport policy: an introduction, Edward Elgar Publishing. 
WARG, J., AIT-ALI, A. \& ELIASSON, J. 2019. Assessment of Commuter Train Timetables Including Transfers. Transportation Research Procedia, 37, 1118.

WETZSTEIN, M. E. 2013. Microeconomic theory: Concepts and connections, second edition, Taylor and Francis. 



\section{Appendix 1: EU directives}

The following Points are excerpts from the SERA directive (EC, 2012).

Point 1 of article 39 on capacity allocation states that:

1. Member States may lay down a framework for the allocation of infrastructure capacity subject to the condition of management independence laid down in Article 4. Specific capacity-allocation rules shall be laid down. The infrastructure manager shall perform the capacity-allocation processes. In particular, the infrastructure manager shall ensure that infrastructure capacity is allocated in a fair and non-discriminatory manner and in accordance with Union law.

Point 4 of article 31 on the principles of track access charges states that:

4. The infrastructure charges referred to in paragraph 3 may include a charge which reflects the scarcity of capacity of the identifiable section of the infrastructure during periods of congestion.

Points 3 and 4 from article 47 on conflict resolution guidelines in congested infrastructures:

3. Where charges in accordance with Article 31(4) have not been levied or have not achieved a satisfactory result and the infrastructure has been declared to be congested, the infrastructure manager may, in addition, employ priority criteria to allocate infrastructure capacity.

4. The priority criteria shall take account of the importance of a service to society relative to any other service which will consequently be excluded. 


\section{Appendix 2: Swedish railway law}

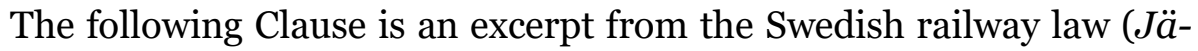
rnvägslagen) on the general guidelines for railway capacity allocation (Riksdag, 2004).

Clause 3 of the $6^{\text {th }}$ chapter from 2004:519 [in Swedish]:

En infrastrukturförvaltare ska bedöma behovet av att organisera tåglägen för olika typer av transporter, inklusive behovet av reservkapacitet. Om ansökningarna om infrastrukturkapacitet inte kan samordnas, ska förvaltaren tilldela kapacitet med hjälp av avgifter eller $i$ enlighet med prioriteringskriterier som medför ett samhällsekonomiskt effektivt utnyttjande av infrastrukturen. 


\section{Included Papers}

The papers associated with this thesis are the following:

P1. A Survey of Railway Deregulation in Europe.

- Submitted for journal publication

P2. Pricing Commercial Train Path Requests Based on Societal Costs.

- $\quad$ Published in

- Transportation Research Part A: Policy and Practice, Volume 132, February 2020, Pages 452-464

$\circ$ https://doi.org/10.1016/i.tra.2019.12.005

P3. Are commuter train timetables consistent with passengers'valuations of waiting times and in-vehicle crowding?

- $\quad$ Submitted for journal publication

P4. Disaggregation in Bundle Methods: Application to the Train Timetabling Problem.

- $\quad$ Published in

○ Journal of Rail Transport Planning \& Management, 100200

○ https://doi.org/10.1016/j.jrtpm.2020.100200

P5. The Value of Additional Data for Public Transport Origin-Destination Matrix Estimation.

- $\quad$ Submitted for journal publication 


\section{Papers}

The papers associated with this thesis have been removed for copyright reasons. For more details about these see:

http://urn.kb.se/resolve?urn=urn:nbn:se:liu:diva-170193 


\section{FACULTY OF SCIENCE AND ENGINEERING}

Linköping Studies in Science and Technology, Dissertation No. 2101, 2020 Department of Science and Technology

Linköping University

SE-60174 Norrköping, Sweden

www.liu.se 